\title{
Toward a Practical, Two-Step Process for Molnupiravir: Direct Hydroxamination of Cytidine Followed by Selective Esterification
}

Dinesh J. Paymode, ${ }^{\dagger}$ N. Vasudevan, ${ }^{\dagger}$ Saeed Ahmad, Appasaheb L. Kadam, Flavio S. P. Cardoso, Justina M. Burns, Daniel W. Cook, Rodger W. Stringham, David R. Snead*

Medicines for All Institute, 737 N 5th St., Box 980100, Richmond, Virginia 23298

\section{Supplemental Information:}

Contents:

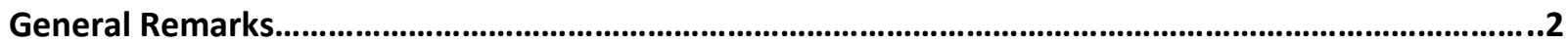

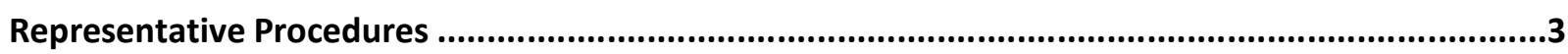

Hydroxylamination of Cytidine: Reaction Screening and Impurity Profile .......................................6

Purification and Isolation of $\mathrm{N}$-Hydroxycytidine Hydrate.................................................................12

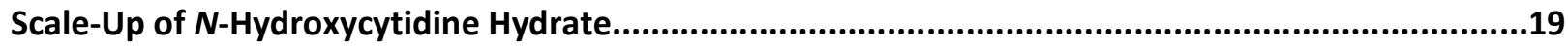

Enzymatic Acylation of $\boldsymbol{N}$-Hydroxycytidine Hydrate: Reaction Optimization and Impurity Profile.......21

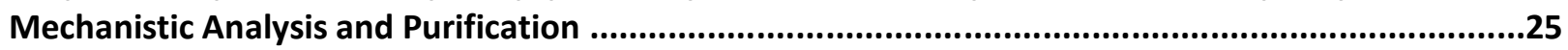

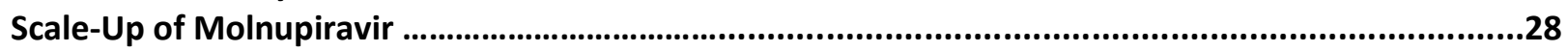

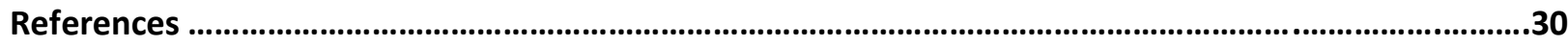

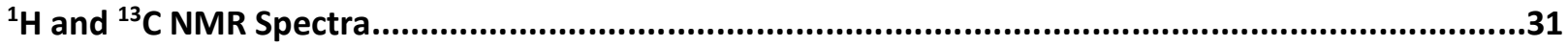

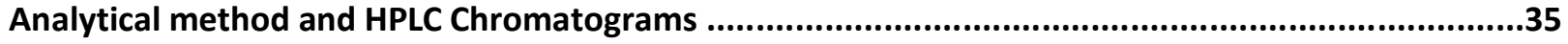




\section{General Remarks:}

Instrumentation: For all compounds, ${ }^{1} \mathrm{H}$ and ${ }^{13} \mathrm{C}$ NMR spectra were recorded on a Bruker Avance III 600 $\mathrm{MHz}$ spectrometer. Chemical shifts were measured relative to the residual solvent resonance for ${ }^{1} \mathrm{H}$ and ${ }^{13} \mathrm{C}$ $\mathrm{NMR}\left(\mathrm{CDCl}_{3}=7.26 \mathrm{ppm}\right.$ for ${ }^{1} \mathrm{H}$ and $77.0 \mathrm{ppm}$ for ${ }^{13} \mathrm{C}$, DMSO- $d_{6}=2.50 \mathrm{ppm}$ for ${ }^{1} \mathrm{H}$ and $39.5 \mathrm{ppm}$ for ${ }^{13} \mathrm{C}$, $\mathrm{CD}_{3} \mathrm{OD}=3.31 \mathrm{ppm}$ for ${ }^{1} \mathrm{H}$ and $49.0 \mathrm{ppm}$ for ${ }^{13} \mathrm{C}, \mathrm{D}_{2} \mathrm{O}=4.79 \mathrm{ppm}$ for ${ }^{1} \mathrm{H}$ ). Coupling constants $J$ are reported in hertz $(\mathrm{Hz})$. The following abbreviations were used to designate signal multiplicity: s, singlet; d, doublet; t, triplet; q, quartet, p, pentet; dd, doublet of doublet; ddd, doublet of doublet of doublet; dt, double of triplet; $\mathrm{ddt}$, doublet of doublet of triplet; m, multiplet; br, broad. Reactions were monitored by HPLC using the methods indicated. Glassware was oven-dried at $120{ }^{\circ} \mathrm{C}$, assembled while hot, and cooled to ambient temperature under an inert atmosphere. Unless noted otherwise, reactions involving air sensitive reagents and/or requiring anhydrous conditions were performed under a nitrogen atmosphere.

Reagents and solvents. Reagents and solvents were purchased from Aldrich Chemical Company, Fisher Scientific, Alfa Aesar, Acros Organics, Oakwood, or TCI. Liquid reagents were purified by distillation when necessary. Unless otherwise noted, solid reagents were used without further purification. Methylene chloride (DCM) and dimethylformamide (DMF) taken from a solid-sorbent Solvent Dispensing System purchased from Pure Process Technologies or distilled as described in the literature. 


\section{Representative Procedures:}

\section{$N$-Hydroxycytidine hydrate 3 (NHC.1H $\left.\mathrm{N}_{2} \mathrm{O}\right)$ (Table S3, entry 5):}

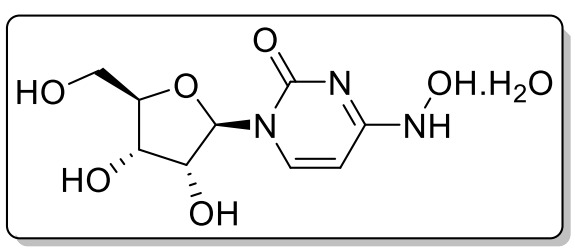

To a 2-L three-neck round bottom flask equipped with an overhead stirrer and a J-KEM internal temperature probe was charged cytidine $(500.00 \mathrm{~g}, 1.0$ equiv., $2.056 \mathrm{~mol})$, hydroxylamine sulphate $(506.12 \mathrm{~g}, 1.5$ equiv., $3.084 \mathrm{~mol})$ and distilled water $(1000 \mathrm{~mL})$. The mixture was stirred with $100 \mathrm{RPM}$ and heated to $70{ }^{\circ} \mathrm{C}$ (internal temperature). The solid suspension was dissolved, and the reaction mixture became homogeneous after 10 minutes. The reaction mixture was stirred total for 5 hours at the same temperature $70{ }^{\circ} \mathrm{C}$ (internal temperature). The reaction was monitored by HPLC, $96 \%$ of cytidine was consumed. The heating was turned off, suspension allowed to slowly cool to ambient temperature $\left(25^{\circ} \mathrm{C}\right)$ over the course of approximately 3 hours, then cooled to an internal temperature $-5^{\circ} \mathrm{C}$ using an ice-salt bath and stirred for additional 3 hours. The solids were isolated by vacuum filtration through Buchner funnel, washed with icecold water $\left(500 \mathrm{~mL} \mathrm{X} \mathrm{3)}\right.$ ) and dried under vacuum oven at $50{ }^{\circ} \mathrm{C}$ for an overnight (16 hours) to afford a white crystalline solid in $84 \%$ yield (477.05 g), with $100 \%$ qNMR assay purity (mesitylene was used as internal standard) and $100 \mathrm{~A} \%$ by HPLC.

${ }^{1} \mathbf{H}$ NMR $\left(600 \mathrm{MHz}, \mathrm{CD}_{3} \mathrm{OD}\right): \delta 7.18(\mathrm{~d}, J=8.4 \mathrm{~Hz}, 1 \mathrm{H}), 5.88(\mathrm{~d}, J=5.7 \mathrm{~Hz}, 1 \mathrm{H}), 5.62(\mathrm{~d}, J=8.3 \mathrm{~Hz}$, $1 \mathrm{H}), 4.18(\mathrm{t}, J=5.5 \mathrm{~Hz}, 1 \mathrm{H}), 4.13(\mathrm{t}, J=4.7 \mathrm{~Hz}, 1 \mathrm{H}), 3.96(\mathrm{~d}, J=3.6 \mathrm{~Hz}, 1 \mathrm{H}), 3.80(\mathrm{dd}, J=12.1,2.9 \mathrm{~Hz}$, $1 \mathrm{H}), 3.71(\mathrm{dd}, J=12.1,3.5 \mathrm{~Hz}, 1 \mathrm{H}) \mathrm{ppm}$.

${ }^{13}$ C NMR (150 MHz, $\left.\mathrm{CD}_{3} \mathrm{OD}\right): \delta 151.8,146.3,132.2,99.3,89.7,86.1,74.6,71.7,62.8 \mathrm{ppm}$. Data matched with those previously reported. ${ }^{1}$

Acetone isobutyryl oxime ester:

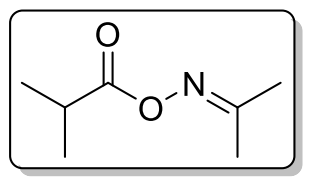

To a 2-L three-neck round bottom flask equipped with an overhead stirrer, a J-KEM internal temperature probe and nitrogen gas inlet was charged acetone oxime (100.0 g, $1.37 \mathrm{~mol}, 1.0$ equiv.), dichloromethane $(1200 \mathrm{~mL})$ and triethylamine $(209.5 \mathrm{~mL}, 1.50 \mathrm{~mol}, 1.1$ equiv.). The reaction mixture stirred with $200 \mathrm{RPM}$ and cooled to an internal temperature $-5{ }^{\circ} \mathrm{C}$ using an ice-salt bath. Then, isobutyryl chloride $(157.7 \mathrm{~mL}$, $1.50 \mathrm{~mol}, 1.1$ equiv.) was added dropwise by maintaining an internal temperature below $0{ }^{\circ} \mathrm{C}$ for 2 hours. The reaction mixture was allowed to warm up to $20^{\circ} \mathrm{C}$ (room temperature) and stirred for 16 hours at the same temperature. The reaction mass was transferred to separating funnel, washed with $\mathrm{H}_{2} \mathrm{O}(250 \mathrm{~mL}), 1 \mathrm{~N}$ $\mathrm{HCl}(250 \mathrm{~mL}), \mathrm{H}_{2} \mathrm{O}(250 \mathrm{~mL})$, saturated solution of $\mathrm{NaHCO}_{3}(250 \mathrm{~mL}), \mathrm{H}_{2} \mathrm{O}(250 \mathrm{~mL})$, and brine solution $(250 \mathrm{~mL})$. The organic layer was dried over anhydrous $\mathrm{Na}_{2} \mathrm{SO}_{4}$, evaporated under vacuum in rotavapor to give desired oxime ester as light-yellow oil (195 g, quantitative yield).

Data matched with those previously reported. ${ }^{1}$

\section{$N$-Hydroxycytidine oxime ester 9:}




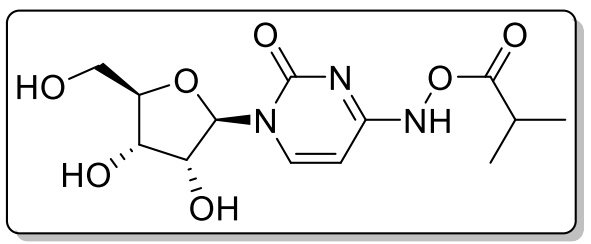

To a stirred, precooled $\left(-20^{\circ} \mathrm{C}\right)$ solution of NHC $3(1.0 \mathrm{~g}, 3.86 \mathrm{mmol}, 1.0$ equiv. $)$ in dry pyridine $(10 \mathrm{~mL})$, isobutyryl chloride $(0.44 \mathrm{~mL}, 4.24 \mathrm{mmol}, 1.1$ equiv. $)$ was added. The reaction mixture was allowed to warm up to $4{ }^{\circ} \mathrm{C}$ and stirred for 20 hours at same temperature. The excess isobutyryl chloride was quenched by $\mathrm{MeOH}(1 \mathrm{~mL})$ and the solvents were removed under reduced pressure. The obtained residue was purified by silica gel column chromatography using dichloromethane in methanol solvents as eluent (0\% to 10\%) to yield the required NHC oxime ester $9(890 \mathrm{mg}, 70 \%)$ as a white solid.

${ }^{1}$ H NMR (600 MHz, CD $\left.{ }_{3} \mathrm{OD}\right): \delta 7.53(\mathrm{~d}, J=8.2 \mathrm{~Hz}, 1 \mathrm{H}), 5.91(\mathrm{~d}, J=5.3 \mathrm{~Hz}, 1 \mathrm{H}), 5.74(\mathrm{~d}, J=8.2 \mathrm{~Hz}$, $1 \mathrm{H}), 4.18(\mathrm{t}, J=5.3 \mathrm{~Hz}, 1 \mathrm{H}), 4.16-4.14(\mathrm{~m}, 1 \mathrm{H}), 3.99(\mathrm{q}, J=3.3 \mathrm{~Hz}, 1 \mathrm{H}), 3.82(\mathrm{dd}, J=12.2,2.9 \mathrm{~Hz}, 1 \mathrm{H})$, $3.73(\mathrm{dd}, J=12.2,3.2 \mathrm{~Hz}, 1 \mathrm{H}), 2.85$ (hept, $J=6.9 \mathrm{~Hz}, 1 \mathrm{H}), 1.24$ (d, $J=7.0 \mathrm{~Hz}, 6 \mathrm{H})$. ppm.

${ }^{13}$ C NMR (150 MHz, $\left.\mathrm{CD}_{3} \mathrm{OD}\right): \delta 176.3,151.2,150.8,136.0,97.3,90.0,86.3,75.1,71.6,62.6,33.6,19.5$ (2C) $\mathrm{ppm}$.

HRMS $(m / z)[\mathrm{M}+\mathrm{Na}]^{+}$calculated for $\mathrm{C}_{13} \mathrm{H}_{19} \mathrm{~N}_{3} \mathrm{O}_{7} \mathrm{Na}$ 352.1121; found 352.1127.

\section{Molnupiravir oxime ester 4:}

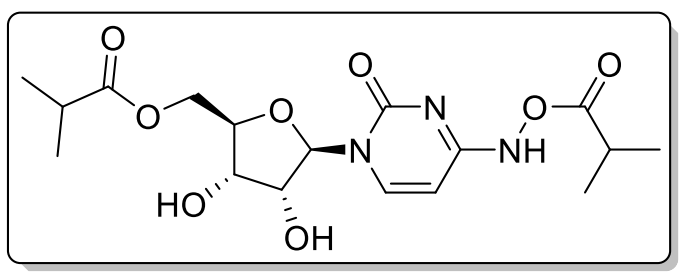

To a stirred, precooled $\left(0{ }^{\circ} \mathrm{C}\right)$ solution of molnupiravir acetonide $(2.0 \mathrm{~g}, 5.42 \mathrm{mmol}, 1.0$ equiv.; synthesized from cytidine in three steps $)^{2}$ in dry pyridine $(20 \mathrm{~mL})$, isobutyryl chloride $(0.62 \mathrm{~mL}, 5.96 \mathrm{mmol}, 1.1$ equiv. $)$ was added. The mixture was gradually warm to room temperature $\left(20^{\circ} \mathrm{C}\right)$ and stirred for 20 hours. The excess isobutyryl chloride was quenched by $\mathrm{MeOH}(1 \mathrm{~mL})$ and the solvents were removed under reduced pressure to obtain the crude molnupiravir acetonide oxime ester as a white foam. The crude material was used for next step without purification.

To a $100 \mathrm{~mL}$ single neck round bottom flask, above crude was dissolved in formic acid $(30 \mathrm{~mL})$ and the resultant solution was stirred at room temperature for 7 hours. Solvent was removed under reduced pressure to afford a waxy solid as a crude product. The obtained residue was purified by silica gel column chromatography using dichloromethane in methanol solvents as eluent (0\% to $10 \%)$ to yield the required molnupiravir oxime ester 4 (1.15 g, 53\% over 2 steps) as a white solid.

${ }^{1} \mathbf{H}$ NMR $\left(600 \mathrm{MHz}, \mathrm{CD}_{3} \mathrm{OD}\right): \delta 7.24(\mathrm{~d}, J=8.2 \mathrm{~Hz}, 1 \mathrm{H}), 5.85(\mathrm{~d}, J=4.6 \mathrm{~Hz}, 1 \mathrm{H}), 5.76(\mathrm{~d}, J=8.2 \mathrm{~Hz}$, $1 \mathrm{H}), 4.36-4.31(\mathrm{~m}, 2 \mathrm{H}), 4.18(\mathrm{t}, J=5.0 \mathrm{~Hz}, 1 \mathrm{H}), 4.14(\mathrm{t}, J=4.3 \mathrm{~Hz}, 1 \mathrm{H}), 4.11(\mathrm{t}, J=5.4 \mathrm{~Hz}, 1 \mathrm{H}), 2.85$ (hept, $J=6.9 \mathrm{~Hz}, 1 \mathrm{H}), 2.65$ (hept, $J=6.6 \mathrm{~Hz}, 1 \mathrm{H}), 1.24(\mathrm{~d}, J=6.9 \mathrm{~Hz}, 6 \mathrm{H}), 1.21(\mathrm{~d}, J=7.0 \mathrm{~Hz}, 6 \mathrm{H}) \mathrm{ppm}$.

${ }^{13} \mathbf{C ~ N M R}\left(150 \mathrm{MHz}, \mathrm{CD}_{3} \mathrm{OD}\right): \delta 178.2,176.3,151.1,150.6,135.5,97.6,90.9,82.8,74.7,71.4,64.8,35.2$, 33.6, 19.5 (2C), 19.4, $19.3 \mathrm{ppm}$.

HRMS $(\mathrm{m} / z)[\mathrm{M}+\mathrm{Na}]^{+}$calculated for $\mathrm{C}_{17} \mathrm{H}_{25} \mathrm{~N}_{3} \mathrm{O}_{8} \mathrm{Na} 422.1539$; found 422.1527 . 
Molnupiravir 1 (MK-4482; EIDD-2801) (Table S10, entry 3):

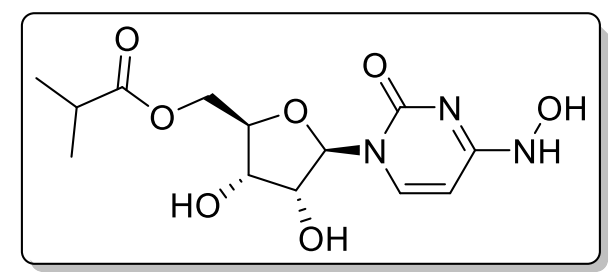

To a 1-L three-neck round bottom flask equipped with an overhead stirrer, a J-KEM internal temperature probe and nitrogen gas inlet was charged $N$-hydroxycytidine hydrate $\left(\mathrm{NHC} 1 \mathrm{H}_{2} \mathrm{O} ; 100.00 \mathrm{~g}, 360.71 \mathrm{mmol}\right.$, 1.0 equiv.), oxime ester (154.94 g, $1.08 \mathrm{~mol}, 3.0$ equiv.), 2-methyltetrahydrofuran (500 mL) and NOVO enzyme-435 10,000 U/G (20.0 g, $20 \mathrm{wt} \%)$ in sequence. The mixture was stirred with $50 \mathrm{RPM}$ and heated to $40{ }^{\circ} \mathrm{C}$ (internal temperature). The reaction was continued for 16 hours at the same temperature. The reaction showed $1.9 \mathrm{~A} \%$ for $\mathrm{NHC}, 66.7 \mathrm{~A} \%$ for molnupiravir and $29.5 \mathrm{~A} \%$ for molnupiravir oxime ester by HPLC at $260 \mathrm{~nm}$. The heating was turned off and the reaction mixture was allowed to cool to ambient temperature $\left(25{ }^{\circ} \mathrm{C}\right)$. The reaction mass was filtered through a Buchner funnel to separate enzyme from reaction mixture, and the enzyme was washed with 2-methyltetrahydrofuran ( 2 X $200 \mathrm{~mL})$. The combined organic layer was transferred to 2-L round bottom flask and hydroxylamine $50 \%$ solution in water $(13 \mathrm{~mL}$, 212.82 mmol, 0.59 equiv.; approx. 2.0 equiv. of molnupiravir oxime ester formed in the reaction) was added. The mixture was stirred at $20{ }^{\circ} \mathrm{C}$ (internal temperature) for 2 hours. The HPLC analysis showed 2.9 $\mathrm{A} \%$ for NHC, $91.7 \mathrm{~A} \%$ for molnupiravir and 3.0 $\mathrm{A} \%$ for molnupiravir oxime ester in the reaction mixture. The solvent was removed under reduced pressure and charged with methyl tert-butylether (MTBE; 1500 $\mathrm{mL})$, stirred at room temperature $\left(20^{\circ} \mathrm{C}\right)$ for 5 hours. The reaction mass was filtered through Buchner funnel, and washed with MTBE ( 2 X $200 \mathrm{~mL})$. The obtained solid was transferred to $500 \mathrm{~mL}$ round bottom flask equipped with an overhead stirrer, a J-KEM internal temperature probe and charged with water (250 $\mathrm{mL}$ ). The suspension was stirred with $50 \mathrm{RPM}$ and heated at $70{ }^{\circ} \mathrm{C}$ (internal temperature) to give a clear solution (approx. 30 minutes). The solution was allowed to cool to room temperature $\left(20{ }^{\circ} \mathrm{C}\right)$ and stirred (50 RPM) overnight (16 hours). The solids were collected by filtration through Buchner funnel, washed with ice-cold water $(2 \mathrm{X} 200 \mathrm{~mL})$, dried under vacuum at $50{ }^{\circ} \mathrm{C}$ for an overnight (16 hours) to afford a white solid product in $71 \%$ yield $(84.31 \mathrm{~g}), 100 \%$ qNMR assay purity (mesitylene was used as internal standard) and $100 \mathrm{~A} \%$ by HPLC.

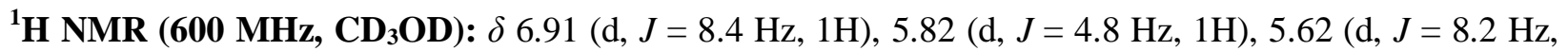
$1 \mathrm{H}), 4.29(\mathrm{~d}, J=3.6 \mathrm{~Hz}, 2 \mathrm{H}), 4.14(\mathrm{t}, J=4.9 \mathrm{~Hz}, 1 \mathrm{H}), 4.10-4.07(\mathrm{~m}, 2 \mathrm{H}), 2.62($ hept $J=6.9 \mathrm{~Hz}, 1 \mathrm{H})$, $1.18(\mathrm{~d}, J=7.0 \mathrm{~Hz}, 6 \mathrm{H}) \mathrm{ppm}$.

${ }^{13}$ C NMR (150 MHz, CD OD): $\delta$ 178.3, 151.5, 146.1, 131.7, 99.5, 90.4, 82.6, 74.4, 71.5, 64.9, 35.1, 19.34, 19.33 ppm. Data matched with those previously reported. ${ }^{1}$ 


\section{Hydroxylamination of Cytidine:}

\section{Reaction Screening and Impurity Profile:}

Table S1: Optimization of $N$-hydroxycytidine from cytidine. ${ }^{a}$

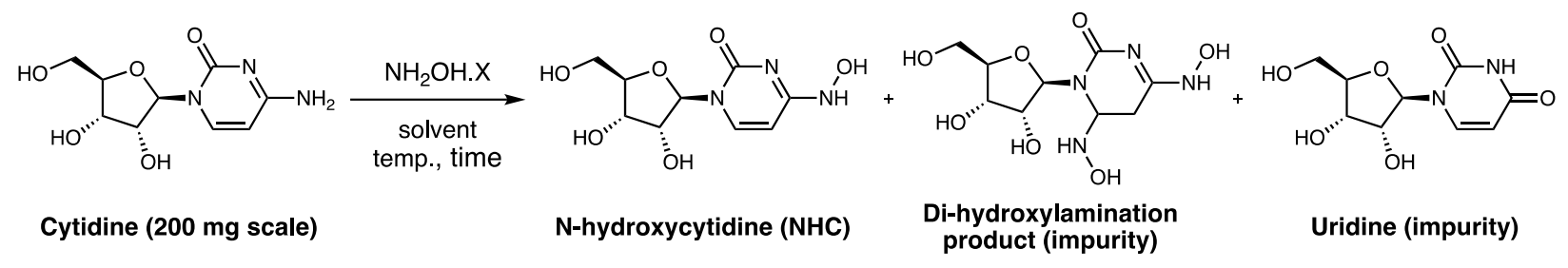

\begin{tabular}{|c|c|c|c|c|c|c|}
\hline \multirow{2}{*}{ Entry } & \multirow{2}{*}{$\mathrm{NH}_{2} \mathrm{OH} . \mathrm{X}$ (equiv.) } & \multirow{2}{*}{ Solvent $(\mathbf{V})$} & \multirow{2}{*}{$\begin{array}{c}\text { Temp. } \\
\left({ }^{\circ} \mathrm{C}\right)\end{array}$} & \multirow{2}{*}{$\begin{array}{c}\text { Time } \\
\text { (h) }\end{array}$} & \multicolumn{2}{|c|}{ LCAP } \\
\hline & & & & & NHC & Uridine \\
\hline $1^{b}$ & $\mathrm{NH}_{2} \mathrm{OH} . \mathrm{HOAc}(3)$ & $\mathrm{H}_{2} \mathrm{O}(20 \mathrm{~V})$ & 40 & 48 & 59.9 & - \\
\hline 2 & $\left(\mathrm{NH}_{2} \mathrm{OH}\right)_{2} \cdot \mathrm{H}_{2} \mathrm{SO}_{4}(4.5)$ & $70 \%{ }^{i} \mathrm{PrOH}$ in $\mathrm{H}_{2} \mathrm{O}(15 \mathrm{~V})$ & 78 & 20 & 94 & 6 \\
\hline 3 & $\left(\mathrm{NH}_{2} \mathrm{OH}\right)_{2} \cdot \mathrm{H}_{2} \mathrm{SO}_{4}(0.5)$ & $70 \%{ }^{i} \mathrm{PrOH}$ in $\mathrm{H}_{2} \mathrm{O}(2 \mathrm{~V})$ & 70 & 16 & 57 & 20 \\
\hline 4 & $\left(\mathrm{NH}_{2} \mathrm{OH}\right)_{2} \cdot \mathrm{H}_{2} \mathrm{SO}_{4}(0.5)$ & $70 \%{ }^{i} \mathrm{PrOH}$ in $\mathrm{H}_{2} \mathrm{O}(15 \mathrm{~V})$ & 70 & 16 & 92 & - \\
\hline 5 & $\left(\mathrm{NH}_{2} \mathrm{OH}\right)_{2} \cdot \mathrm{H}_{2} \mathrm{SO}_{4}(1.5)$ & $70 \%{ }^{i} \mathrm{PrOH}$ in $\mathrm{H}_{2} \mathrm{O}(2 \mathrm{~V})$ & 70 & 16 & 29 & 71 \\
\hline 6 & $\left(\mathrm{NH}_{2} \mathrm{OH}\right)_{2} \cdot \mathrm{H}_{2} \mathrm{SO}_{4}(1.5)$ & $70 \%{ }^{i} \mathrm{PrOH}$ in $\mathrm{H}_{2} \mathrm{O}(15 \mathrm{~V})$ & 70 & 16 & 98 & 2 \\
\hline 7 & $\left(\mathrm{NH}_{2} \mathrm{OH}\right)_{2} \cdot \mathrm{H}_{2} \mathrm{SO}_{4}(0.75)$ & $70 \%{ }^{i} \mathrm{PrOH}$ in $\mathrm{H}_{2} \mathrm{O}(10 \mathrm{~V})$ & 40 & 22 & 73 & - \\
\hline 8 & $\left(\mathrm{NH}_{2} \mathrm{OH}\right)_{2} \cdot \mathrm{H}_{2} \mathrm{SO}_{4}(0.75)$ & $70 \%{ }^{i} \mathrm{PrOH}$ in $\mathrm{H}_{2} \mathrm{O}(10 \mathrm{~V})$ & 70 & 22 & 97 & 3 \\
\hline 9 & $\left(\mathrm{NH}_{2} \mathrm{OH}\right)_{2} \cdot \mathrm{H}_{2} \mathrm{SO}_{4}(0.75)$ & ${ }^{i} \mathrm{PrOH}(10 \mathrm{~V})$ & 70 & 16 & - & - \\
\hline 10 & $\left(\mathrm{NH}_{2} \mathrm{OH}\right)_{2} \cdot \mathrm{H}_{2} \mathrm{SO}_{4}(0.75)$ & $95 \%{ }^{i} \mathrm{PrOH}$ in $\mathrm{H}_{2} \mathrm{O}(10 \mathrm{~V})$ & 70 & 16 & 78 & - \\
\hline 11 & $\left(\mathrm{NH}_{2} \mathrm{OH}\right)_{2} \cdot \mathrm{H}_{2} \mathrm{SO}_{4}(0.75)$ & $90 \%{ }^{i} \mathrm{PrOH}$ in $\mathrm{H}_{2} \mathrm{O}(10 \mathrm{~V})$ & 70 & 16 & 77 & 23 \\
\hline 12 & $\left(\mathrm{NH}_{2} \mathrm{OH}\right)_{2} \cdot \mathrm{H}_{2} \mathrm{SO}_{4}(0.75)$ & $\mathrm{H}_{2} \mathrm{O}(10 \mathrm{~V})$ & 70 & 16 & 95 & 5 \\
\hline 13 & $\left(\mathrm{NH}_{2} \mathrm{OH}\right)_{2} \cdot \mathrm{H}_{2} \mathrm{SO}_{4}(0.75)$ & $\mathrm{H}_{2} \mathrm{O}(2 \mathrm{~V})$ & 70 & 24 & 88 & 2 \\
\hline 14 & $\left(\mathrm{NH}_{2} \mathrm{OH}\right)_{2} \cdot \mathrm{H}_{2} \mathrm{SO}_{4}(0.75)$ & $\mathrm{H}_{2} \mathrm{O}(5 \mathrm{~V})$ & 70 & 24 & 90 & 10 \\
\hline 15 & $\left(\mathrm{NH}_{2} \mathrm{OH}\right)_{2} \cdot \mathrm{H}_{2} \mathrm{SO}_{4}(1.5)$ & $\mathrm{H}_{2} \mathrm{O}(2 \mathrm{~V})$ & 70 & 6 & 95 & 6 \\
\hline 16 & $\left(\mathrm{NH}_{2} \mathrm{OH}\right)_{2} \cdot \mathrm{H}_{2} \mathrm{SO}_{4}(1.5)$ & $\mathrm{H}_{2} \mathrm{O}(5 \mathrm{~V})$ & 70 & 6 & 94 & 6 \\
\hline
\end{tabular}

${ }^{a}$ Reaction Conditions: cytidine (200 mg), hydroxylamine reagent $\left(\mathrm{NH}_{2} \mathrm{OH} . \mathrm{X}\right)$, solvent, temperature and time. ${ }^{b} 33.8 \mathrm{~A} \%$ Di-hydroxylamination product was observed in HPLC at $210 \mathrm{~nm}$.

At the outset, NHC was synthesized from cytidine following Purohit et al reaction conditions ${ }^{3}$ and reaction conditions were further optimized by varying the amount of hydroxylamine acetate. In the best scenario, 
the starting cytidine was consumed with the use of 3 equiv. of hydroxylamine acetate at $40{ }^{\circ} \mathrm{C}$ in 48 hours, monitored by HPLC (Table S1, entry 1). Although, the reaction mixture showed single peak for product at 1.532 in the HPLC at $260 \mathrm{~nm}$ wavelength (Figure S1a), the ${ }^{1} \mathrm{H}$ NMR was very complex (Figure S2a) and provided 57\% in-process assay yield by qNMR (dimethyl sulfone was used as internal standard). After further evaluation, the HPLC showed additional peak for impurity at 1.482 along with NHC at $210 \mathrm{~nm}$ wavelength (Figure S1b). The impurity (HPLC peak at 1.482) was characterized using LCMS and it was found that the NHC was over-hydroxylaminated to form the di-hydroxylamination product.

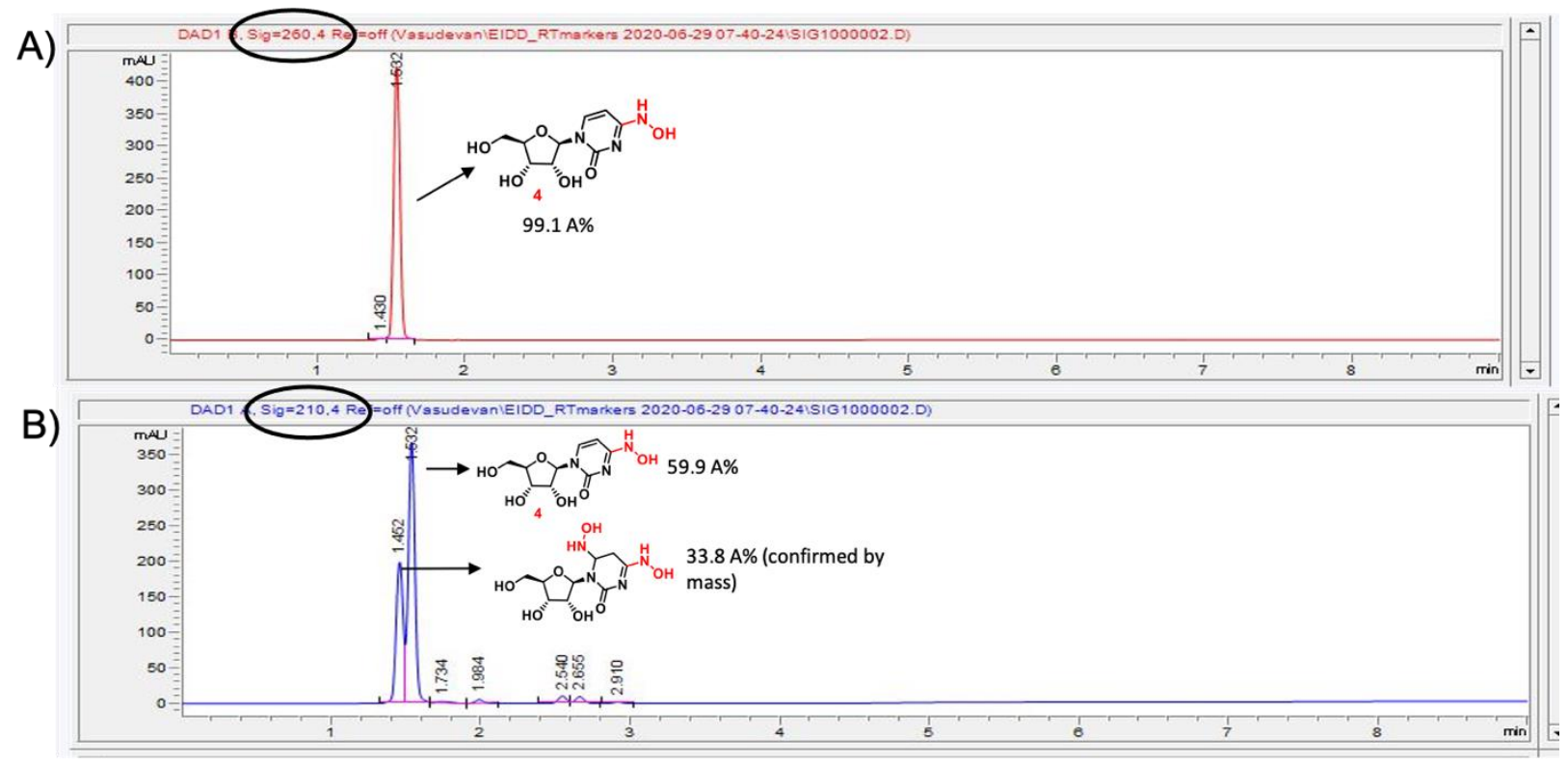

Figure S1: A) The HPLC chromatogram for the reaction at $260 \mathrm{~nm}$ wavelength. B) The HPLC chromatogram for the reaction at $210 \mathrm{~nm}$ wavelength.

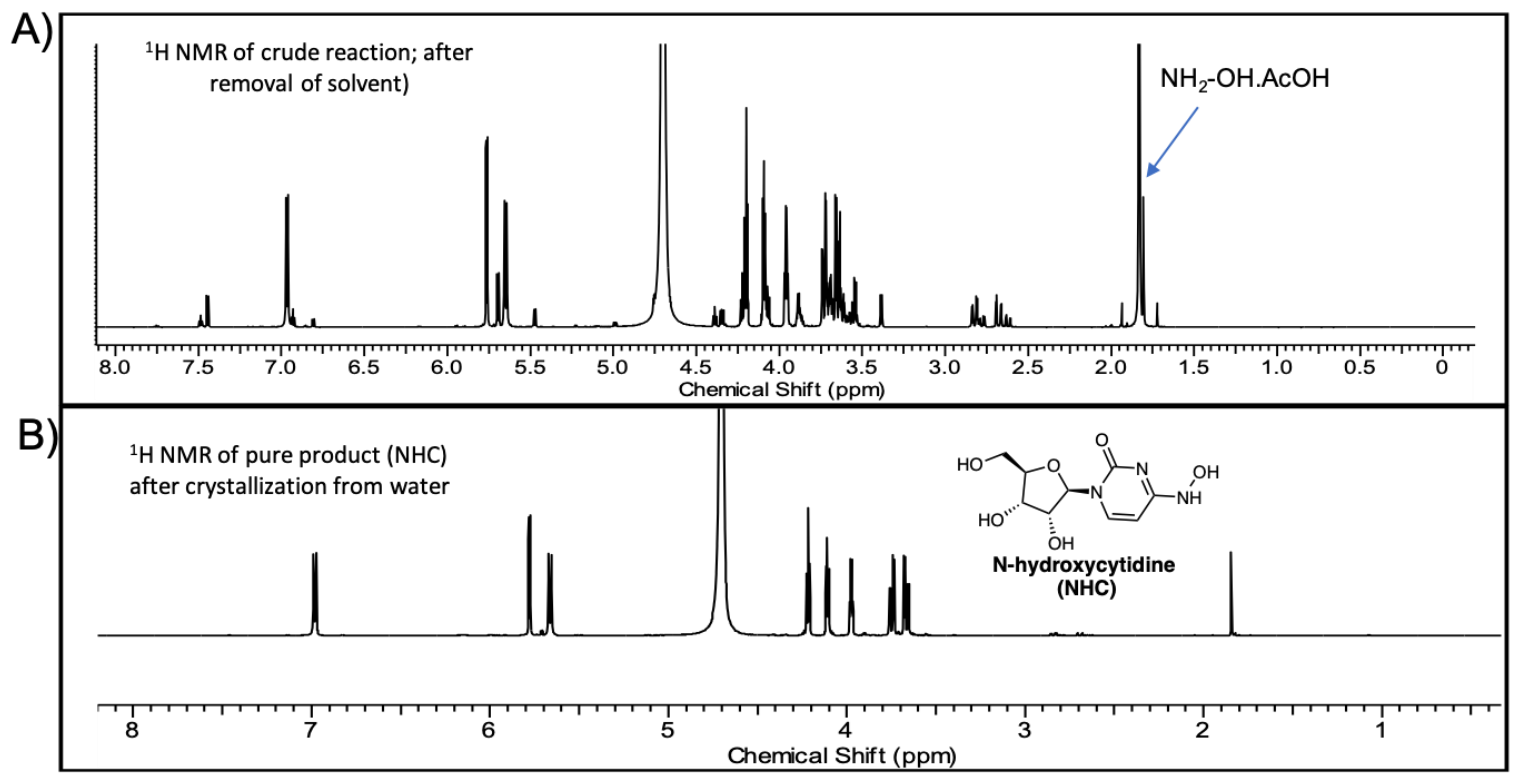

Figure S2: A) The ${ }^{1} \mathrm{H}$ NMR of crude reaction mixture. B) The ${ }^{1} \mathrm{H}$ NMR of pure product (NHC) after recrystallization. 
Next, the crude reaction mixture was concentrated under reduced pressure and the obtained solid was recrystallized from water. The recrystallized product was collected by filtration and dried. The desired NHC was obtained in $50 \%$ yield with $92 \%$ purity (by qNMR; Figure S2b).

Recently, we demonstrated the use of hydroxylamine sulphate for hydroxylamination of 5'-Oisobutyrylcytidine to provide EIDD-2801 with the help of hydroxylamine sulphate. The similar reaction conditions were attempted for synthesis of NHC from cytidine (Table S1, entry 2). The reaction was carried out with hydroxylamine sulphate $\left(4.5\right.$ equiv.) in isopropanol/water mixture $(70 \% ; 15 \mathrm{~V})$ at $78{ }^{\circ} \mathrm{C}$. Surprisingly, cytidine was completely consumed and the peak for di-hydroxylamination product (impurity) was not found in the HPLC at $210 \mathrm{~nm}$.

\section{Exploring effect of amount of hydroxylamine sulphate and solvent on reaction:}

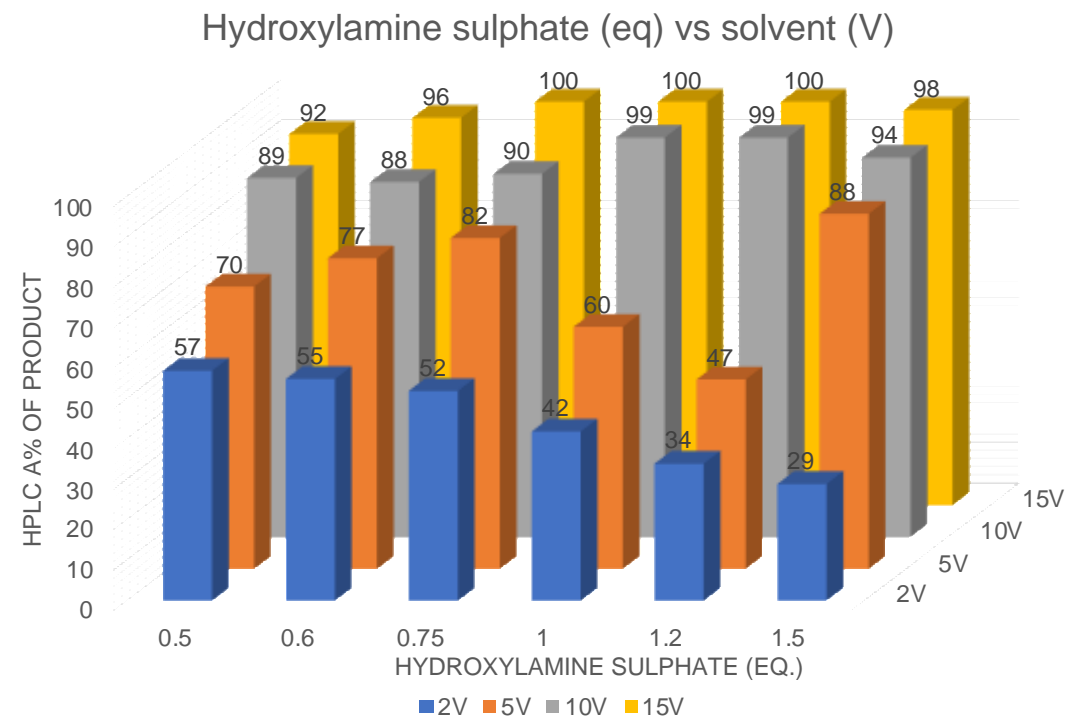

The set of 24 reactions on $200 \mathrm{mg}$ scale were carried with different equivalents of hydroxylamine sulphate and at different concentrations. These experiments showed that the amount of hydroxylamine sulphate can be reduced from 4.5 equivalents to up to 0.75 equivalents and the volume of solvent can be reduced from $15 \mathrm{~V}$ to $5 \mathrm{~V}$ (Table $\mathrm{S} 1$, entry 3 to 6 ). Interestingly, the reactions with lower volume of solvents ( $2 \mathrm{~V}$ and $5 \mathrm{~V}$ ) were heterogeneous in nature and the reactions with higher volume of solvents (10V and $15 \mathrm{~V})$ were homogeneous but biphasic in nature (Figure S3).

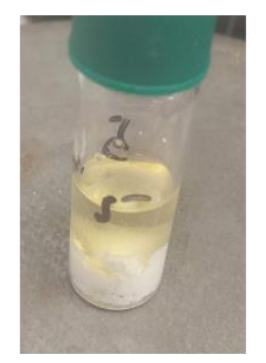

In $2 \mathrm{~V}$ and $5 \mathrm{~V}$ (heterogeneous RM)

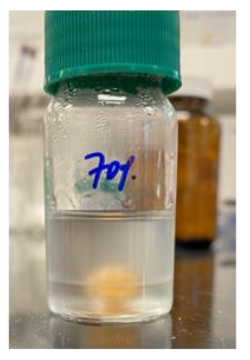

In $10 \mathrm{~V}$ and $15 \mathrm{~V}$ (biphasic mixture)

Figure S3: Reaction mixtures after completion of reactions. 
Besides these results, we observed a new peak (impurity) at 1.607 in HPLC of reaction mixtures, where the product $\mathrm{A} \%$ was less, rather the reaction mixtures where solvent volumes were less $(2 \mathrm{~V}$ and $5 \mathrm{~V})$. The impurity at 1.609 was characterized as uridine by using LCMS. Additionally, the retention time of the impurity and commercial uridine sample were found comparable in the HPLC chromatograms (Figure S4).

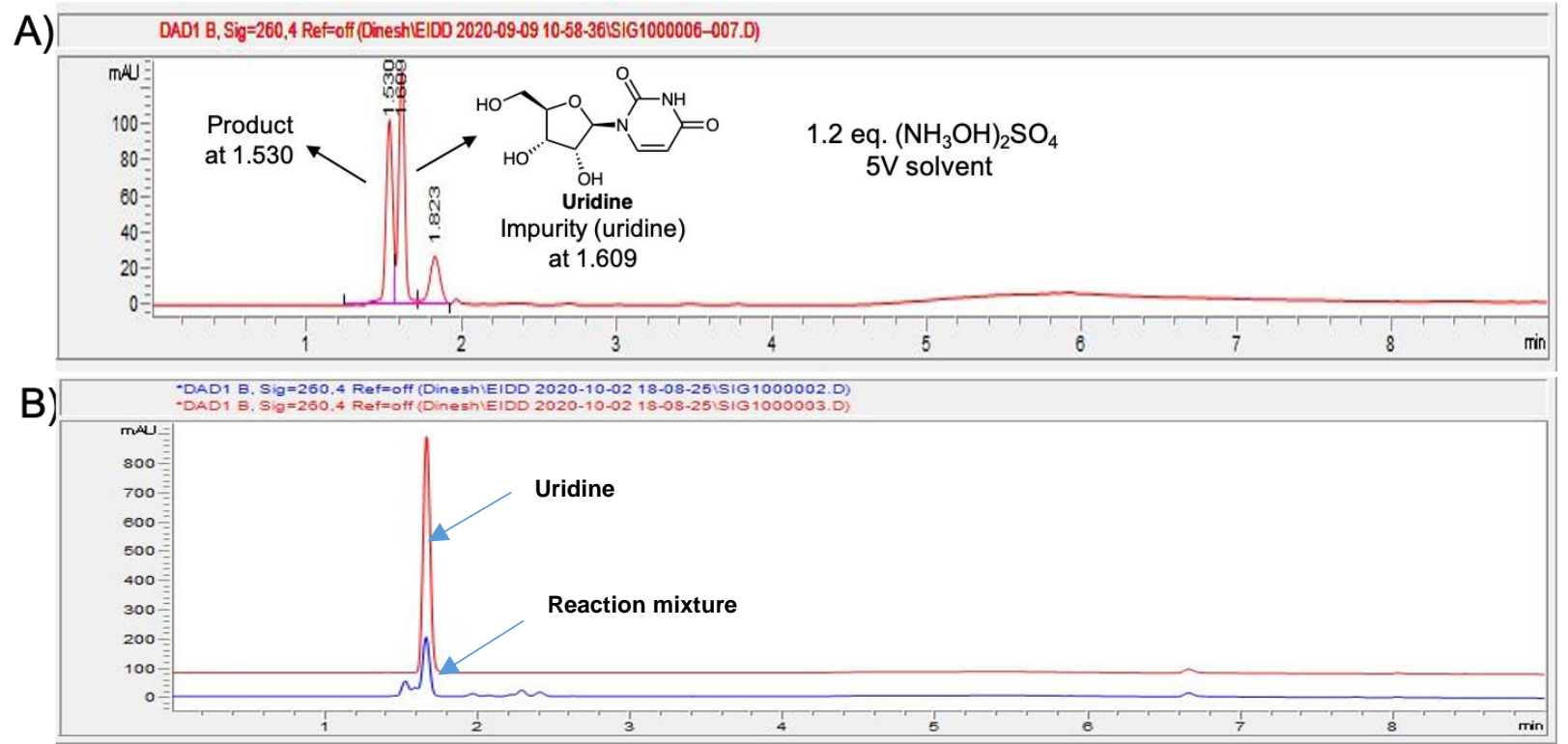

Figure S4: A) The HPLC chromatogram for the reaction mixture (1.2 equiv. $\left(\mathrm{NH}_{2} \mathrm{OH}\right)_{2} \cdot \mathrm{H}_{2} \mathrm{SO}_{4}$ and $5 \mathrm{~V}$ solvent) showing product peak at 1.530 and impurity peak at 1.609. B) The HPLC chromatogram for comparison of commercial uridine and reaction mixture $\left\{1.5\right.$ equiv. $\left(\mathrm{NH}_{2} \mathrm{OH}\right)_{2} \cdot \mathrm{H}_{2} \mathrm{SO}_{4}$ and $2 \mathrm{~V}$ solvent $\}$.

\section{Reaction kinetics at different temperatures:}

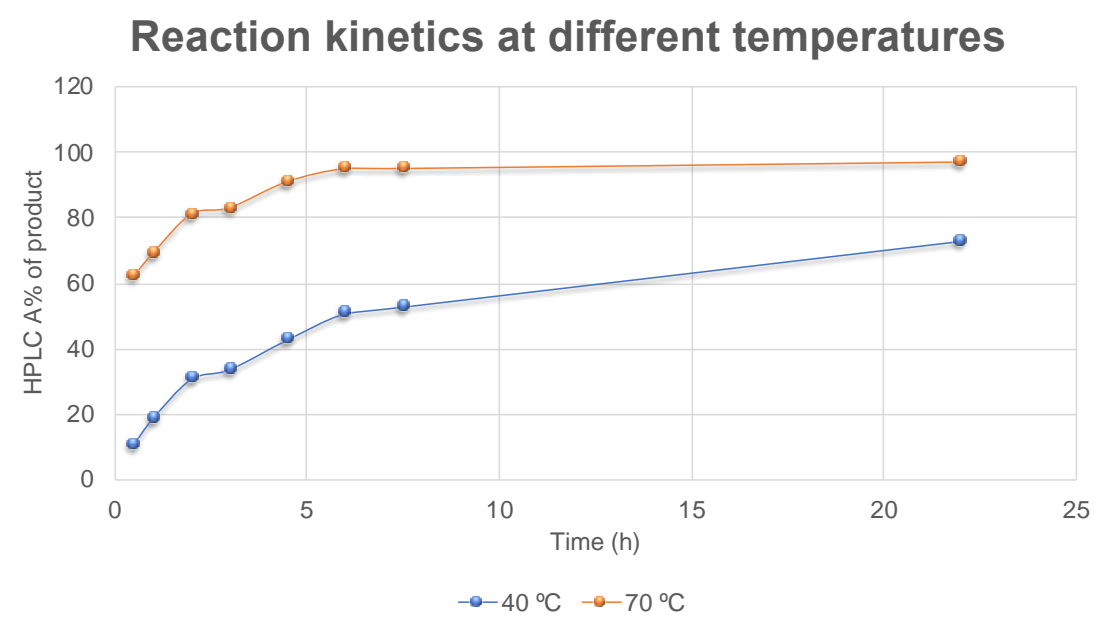

The set of two reactions were carried out at $40{ }^{\circ} \mathrm{C}$ and $70{ }^{\circ} \mathrm{C}$ on a $200 \mathrm{mg}$ scale and the reactions were monitored at different time intervals. The reaction was incomplete at $40{ }^{\circ} \mathrm{C}$ even after $22 \mathrm{~h}$, whereas $27 \%$ starting cytidine was left in the reaction mixture (Table S1, entry 7). In case of the reaction at $70{ }^{\circ} \mathrm{C}$, the starting cytidine was completely consumed in 22 hours, showing $97 \%$ product (NHC) and 3\% of uridine (impurity) by HPLC (Table S1, entry 8). Importantly, the peak for uridine was not observed on HPLC up to 8 hours of heating at $70^{\circ} \mathrm{C}$. This experiment clearly indicates that the reaction requires $70{ }^{\circ} \mathrm{C}$ temperature and prolonged heating causes uridine formation. 
Exploring the effect of ratio of isopropanol and water on reaction:

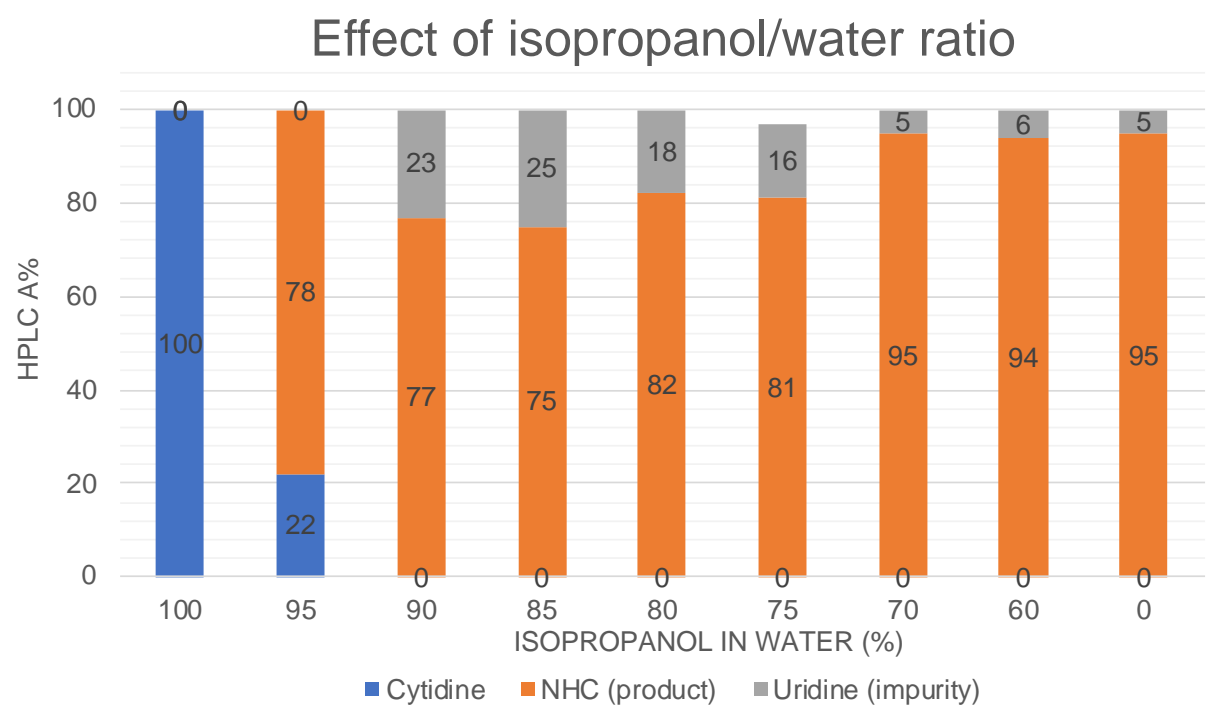

The starting cytidine was found unreacted, when the reaction was conducted in isopropanol as only solvent (Table S1, entry 9). The reactions worked smoothly, cytidine was consumed, and the uridine (impurity) formation was lowered when water quantity was increased in the reactions (Table S1, entry 10 to 12).

Reaction kinetics at different concentrations ( 0.75 equiv. of $\left.\left(\mathrm{NH}_{2} \mathrm{OH}\right)_{2} \cdot \mathrm{H}_{2} \mathrm{SO}_{4}\right)$ :

Reaction kinetics at different conc.

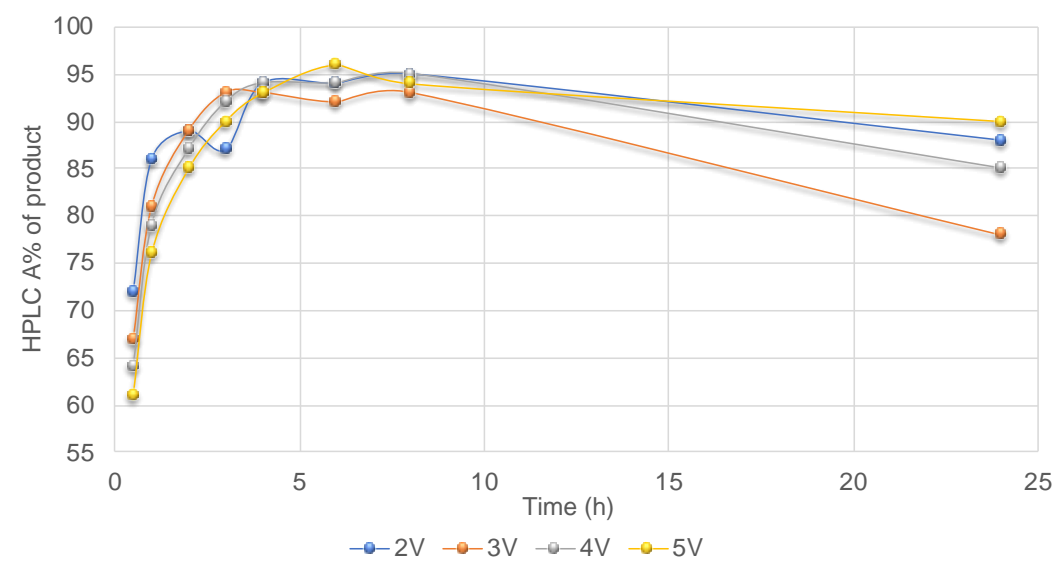

Reaction kinetics at different concentrations (1.5 equiv. of $\left.\left(\mathrm{NH}_{2} \mathrm{OH}\right)_{2} \cdot \mathrm{H}_{2} \mathrm{SO}_{4}\right)$ : 


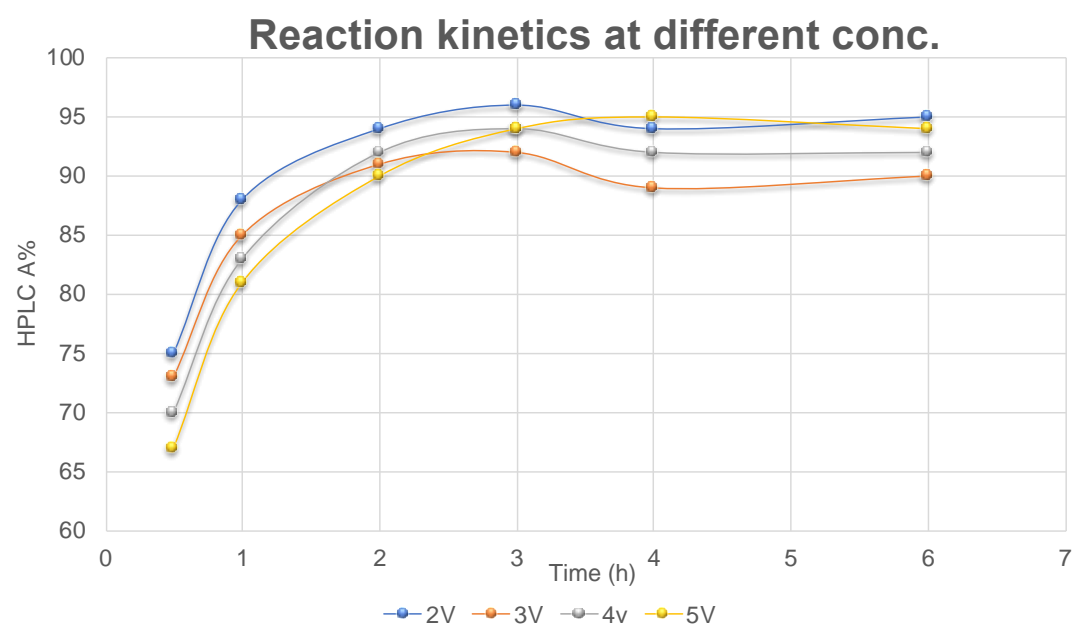

The set of 8 reactions were carried out to understand the effect of concentrations on the rate of reactions and uridine formation. In the previous studies, we had observed non-homogeneous reactions mixtures in isopropanol/water $(2 \mathrm{~V}$ and $5 \mathrm{~V})$ to provide low product and high side-product (uridine), however, the reactions were homogeneous in water. The rate of reactions was directly proportional to the concentration of reactions $(2 \mathrm{~V}>3 \mathrm{~V}>4 \mathrm{~V}>5 \mathrm{~V})$ and the amount of hydroxylamine sulphate (1.5 equiv. $>0.75$ equiv.). The consumption of cytidine was stopped, and uridine (impurity) formation started after 6 hours (Table S1, entry 13 to 16$)$. The overall optimized reaction conditions were as hydroxylamine sulphate $(0.75$ equiv. to 1.5 equiv.), water as a solvent $(2 \mathrm{~V}$ to $5 \mathrm{~V})$, reaction temperature $70^{\circ} \mathrm{C}$, and the reaction time was $5 \mathrm{~h}$ to $6 \mathrm{~h}$. 


\section{Purification and Isolation of the $N$-Hydroxycytidine Hydrate:}

Table S2: 1 Gram scale reaction and isolation of product. ${ }^{a}$

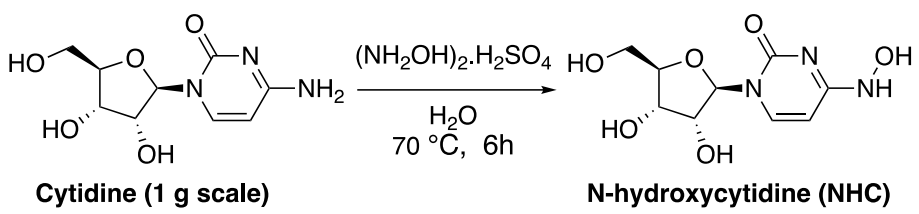

\begin{tabular}{|c|c|c|c|c|c|c|}
\hline \multirow{2}{*}{ Entry } & \multirow{2}{*}{$\begin{array}{c}\left.\mathbf{N H}_{2} \mathbf{O H}\right)_{2} \mathbf{H}_{2} \mathbf{S O}_{4} \\
\text { (equiv.) }\end{array}$} & \multirow{2}{*}{$\begin{array}{c}\mathbf{H}_{2} \mathbf{O} \\
\text { Volumes (V) }\end{array}$} & \multicolumn{2}{|c|}{ LCAP(cytidine/NHC) } & \multirow{2}{*}{$\begin{array}{c}\text { Purity by } \\
\text { qNMR }^{b}\end{array}$} & \multirow{2}{*}{ Yield $^{c}$} \\
\cline { 4 - 7 } & 0.75 & $2 \mathrm{~V}$ & $16 / 84$ & - & 81 & 70 \\
\hline 1 & 0.75 & $5 \mathrm{~V}$ & $21 / 79$ & $13 / 87$ & 84 & 82 \\
\hline 3 & 1.5 & $2 \mathrm{~V}$ & $8 / 92$ & - & 85 & 84 \\
\hline 4 & 1.5 & $5 \mathrm{~V}$ & $11 / 89$ & $5 / 95$ & 87 & 82 \\
\hline
\end{tabular}

${ }^{a}$ Reaction Conditions: cytidine $(1 \mathrm{~g})$, hydroxylamine sulphate, water, $70{ }^{\circ} \mathrm{C}$ and $6 \mathrm{~h} .{ }^{b} \mathrm{DMSO}-d_{6}$ was used as a solvent and mesitylene was used as an internal standard. ${ }^{c}$ Yields are adjusted with qNMR purity.

The $1 \mathrm{~g}$ scale reactions were attempted with the optimized reaction conditions and tried to isolate the product (Table S2). The reactions were stopped before 6 hours to avoid formation of uridine. The procedure for the above reactions is as follows:

Procedure: To the suspension of cytidine $(1.0 \mathrm{~g}, 4.11 \mathrm{mmol}, 1.0$ equiv.) in water (2V or $5 \mathrm{~V})$, hydroxylamine sulphate $\left(0.75\right.$ equiv. or 1.5 equiv.) was added and reactions was heated to $70{ }^{\circ} \mathrm{C}$ for $3 \mathrm{~h}$ or $6 \mathrm{~h}$. The reactions were monitored by using HPLC. The reaction mixtures were allowed to cool at room temperature over time and then cooled to $4{ }^{\circ} \mathrm{C}$ for overnight. The solid products were filtered through the Buchner funnel, washed with ice-cold water and dried in a vacuum oven at $50{ }^{\circ} \mathrm{C}$. The purities of products were analyzed by qNMR (in DMSO- $d_{6}$; mesitylene was used as internal standard). The yields of the reactions were in the range of $70 \%$ to $84 \%$ (adjusted with qNMR purity). 
${ }^{1} \mathrm{H}$ NMR (in DMSO-d $d_{6}$ ) of NHC obtained from reaction:

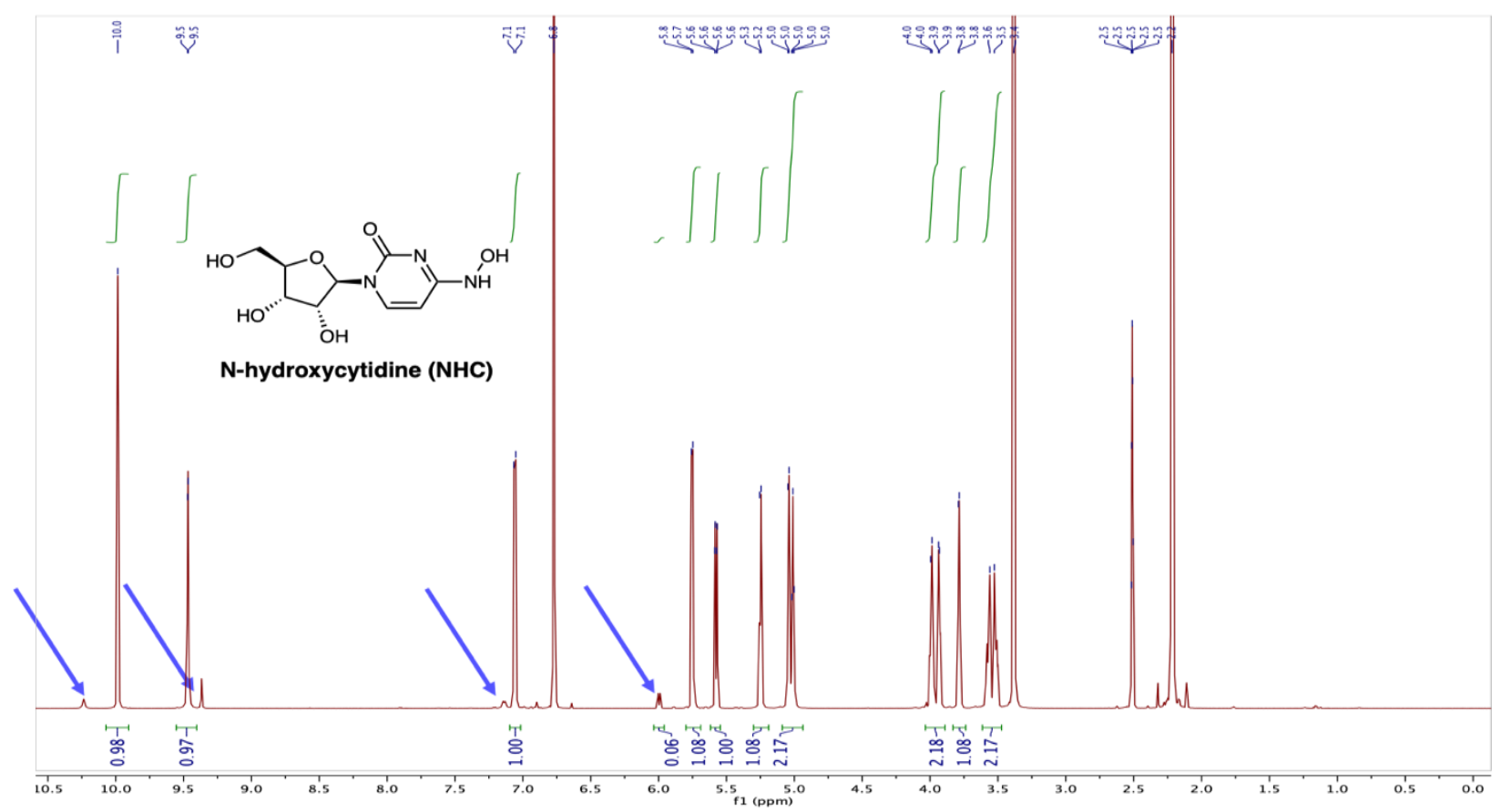

In the ${ }^{1} \mathrm{H}$ NMR of product (NHC), some minor peaks were observed and considered them responsible for lower purities of products ( $81 \%$ to $87 \%)$.

Solvent screening for recrystallization of NHC (100 mg product in $1 \mathrm{~mL}$ solvent):

\begin{tabular}{|l|l|l|l|l|l|}
\hline Sr. No. & Solvent & Room Temp. & $50^{\circ} \mathrm{C}$ & Reflux & Return to rt \\
\hline 1. & Water & & & & \\
\hline 2. & $\mathrm{MeOH}$ & & & & \\
\hline 3. & EtOH & & & & \\
\hline 4. & iPrOH & & & & \\
\hline 5. & nBuOH & & & & \\
\hline 6. & EtOAc & & & & \\
\hline 7. & iPrOAc & & & & \\
\hline 8. & Acetone & & & & \\
\hline 9. & Acetonitrile & & & & \\
\hline 10. & THF & & & & \\
\hline 11. & $1,4-$ dioxane & & & & \\
\hline 12. & Toluene & & & & \\
\hline
\end{tabular}




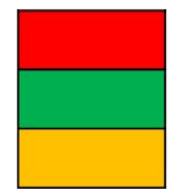

Insoluble
Soluble
Recrystallized

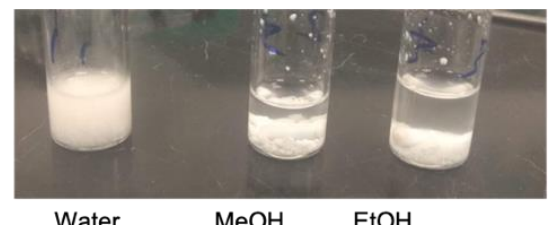

At the outset, different solvents were screened for recrystallization of NHC (above table). In exception to water, methanol and ethanol, NHC was not found soluble in any other solvents even at reflux temperature. Those three samples provided solids after cooling (room temperature). The nice crystalline product was obtained from water with good recovery. On the other hand, the product solidified from the methanol and ethanol were in the form of powder and provided low recovery.

\section{Amount of water screening for recrystallization of NHC (100 mg product in water):}

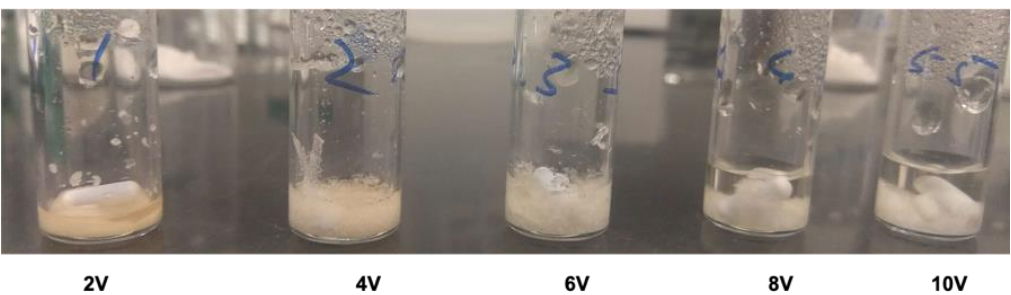

Comparison of ${ }^{1} \mathrm{H}$ NMR (in DMSO- $d_{6}$ ) of NHC recrystallized from water:

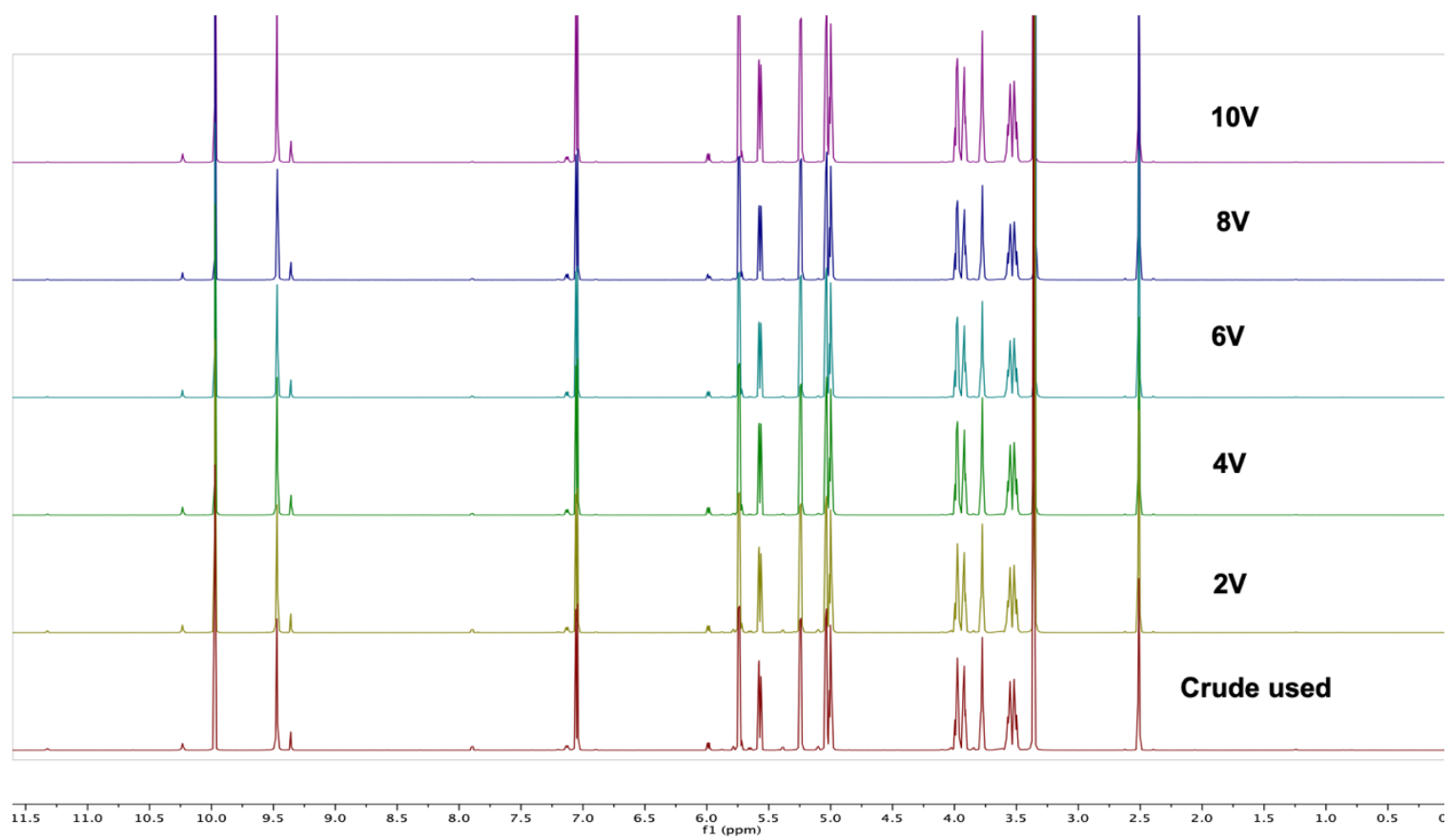

Later, recrystallization of NHC was attempted with different quantities of water ( $2 \mathrm{~V}$ to $10 \mathrm{~V}$ ). The recovery of the product was lower with higher amounts of water. The recrystallized products were filtered, dried and subjected for qNMR. Unfortunately, all samples approximately gave the same purity as crude used for recrystallization (83\% to $87 \%$ ). The minor peaks were found as such in ${ }^{1} \mathrm{H}$ NMR (DMSO- $d_{6}$ ). 
Purity issue: Tautomers???<smiles>CC(C)COC1OC(n2ccc(=NO)[nH]c2=O)[C@H](O)[C@@H]1O</smiles>

1. Variable Temperature (VT) NMR study ( ${ }^{1} \mathrm{H}$ NMR in DMSO-d ${ }_{6}$ ):

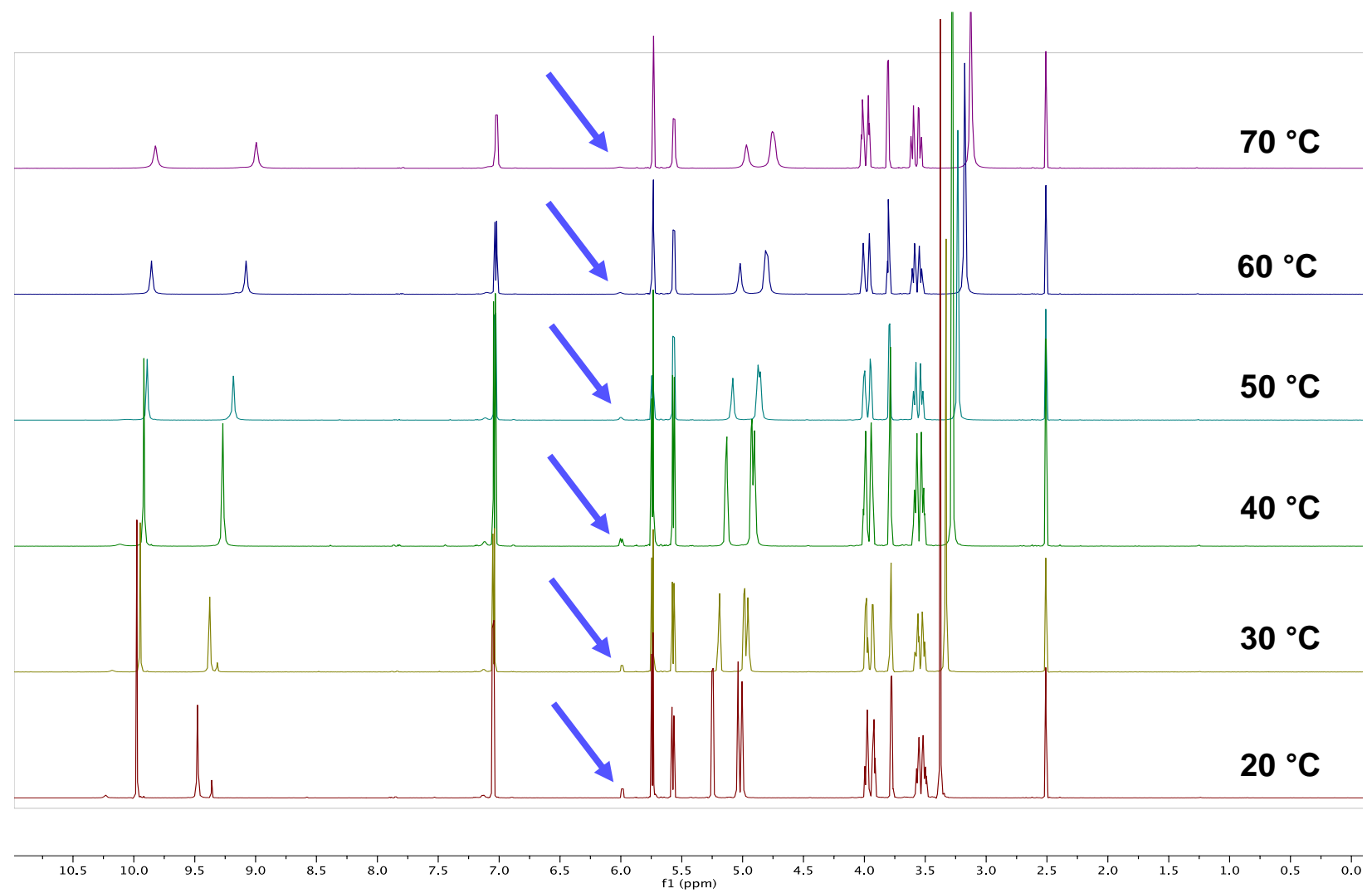

The NHC was subjected to variable temperature (VT) NMR study. The ${ }^{1} \mathrm{H}$ NMR of NHC was recorded at different temperatures (from $20{ }^{\circ} \mathrm{C}$ to $70{ }^{\circ} \mathrm{C}$ ) in DMSO- $d_{6}$ ). The NMR at $20{ }^{\circ} \mathrm{C}$ showed about 5-6\% peaks for minor isomer. The peaks for minor isomer were disappeared in the NMR recorded at higher temperature $\left(70{ }^{\circ} \mathrm{C}\right)$ as the minor isomer could convert to major isomer.

\begin{tabular}{|c|c|c|c|c|}
\hline Entry & $\begin{array}{c}\text { Temp. } \\
\left({ }^{\circ} \mathrm{C}\right)\end{array}$ & $\begin{array}{c}\text { Major isomer } \\
(\boldsymbol{\%}, \mathbf{5 . 5 6} \mathbf{~ p p m})\end{array}$ & $\begin{array}{c}\text { Minor isomer } \\
(\boldsymbol{\%}, \mathbf{5 . 9 8} \mathbf{~ p p m})\end{array}$ & $\begin{array}{c}\text { Combined } \\
\text { NHC }(\boldsymbol{\%})\end{array}$ \\
\hline 1 & 20 & 94.22 & 5.78 & 92.70 \\
\hline 2 & 30 & 94.19 & 5.81 & 92.32 \\
\hline 3 & 40 & 95.00 & 5.00 & 92.84 \\
\hline 4 & 50 & 95.87 & 4.13 & 92.91 \\
\hline 5 & 60 & 96.79 & 3.21 & 92.78 \\
\hline 6 & 70 & 97.86 & 2.14 & 92.79 \\
\hline
\end{tabular}


2. ${ }^{1}$ H NMRs in different deuterated solvents:
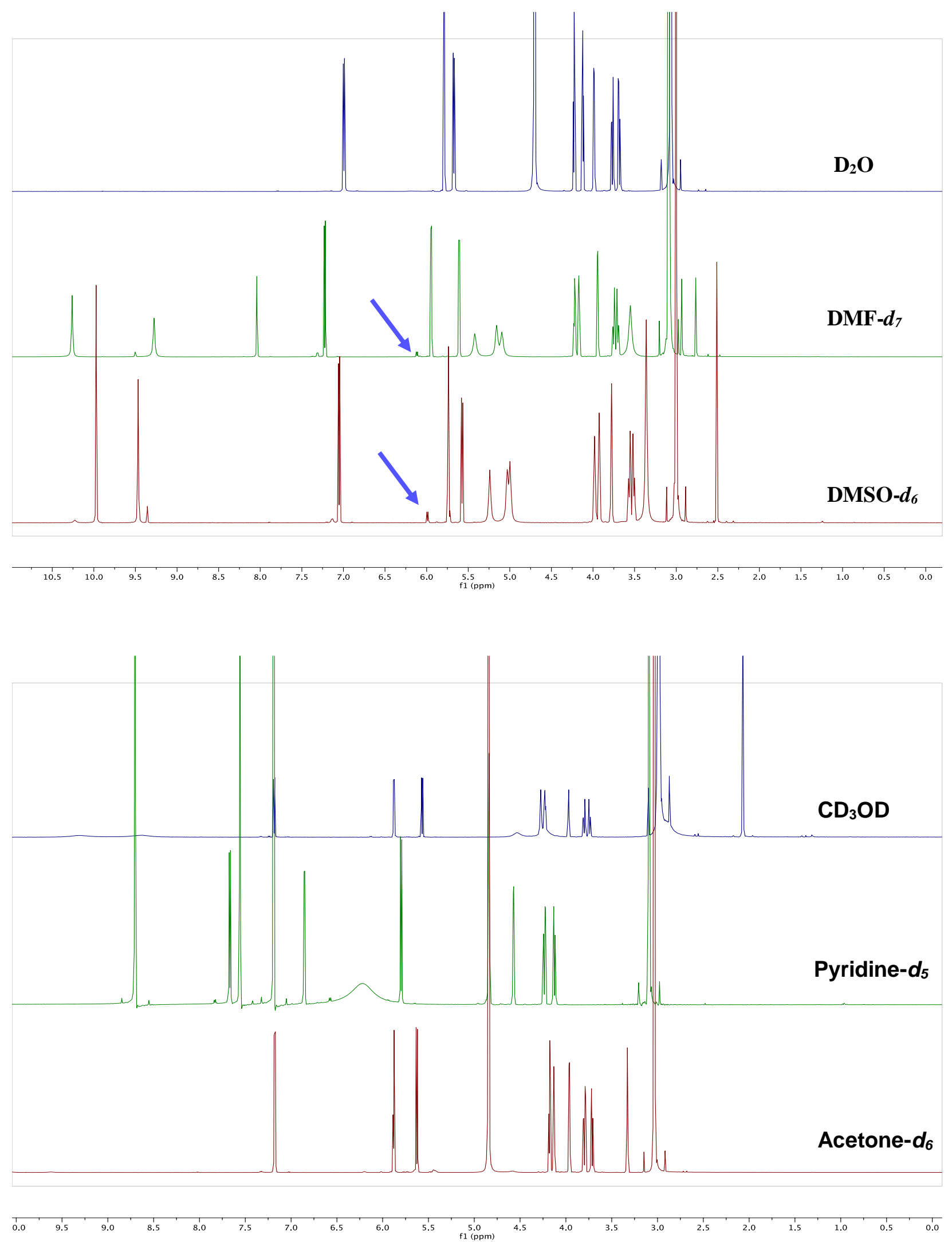
The ${ }^{1} \mathrm{H}$ NMR of NHC were recorded in different deuterated solvents to check their effect on minor peaks. In DMSO- $d_{6}$ and DMF- $d_{7}$ the NHC showed peaks for both isomers (observed minor peaks), while in $\mathrm{D}_{2} \mathrm{O}$, $\mathrm{CD}_{3} \mathrm{OD}$, pyridine- $d_{5}$ and acetone- $d_{6}$ single compound (only one isomer) was observed. This clearly indicated that the ratio of tautomers changed with respect to the solvent. Additionally, these ${ }^{1} \mathrm{H}$ NMR used to check the purity of NHC by adding dimethyl sulfone as an internal standard. The purities obtained for NHC in different deuterated solvents were as follows.

1. DMSO- $d_{6}=93 \%$ (by adding minor and major peaks)

2. DMF- $d_{7}=94 \%$ (by adding minor and major peaks)

3. $\mathrm{D}_{2} \mathrm{O}=93 \%$

4. $\mathrm{CD}_{3} \mathrm{OD}=93 \%$

5. pyridine- $d_{5}=94 \%$

6. acetone- $d_{6}=22 \%$ (NHC was completely soluble in acetone)

Although the purities obtained by qNMR in different solvents were not $>94 \%$, but the numbers were consistent.

\section{Crystal structure of NHC (recrystallized from water):}

\section{CCDC No.: 2044828}
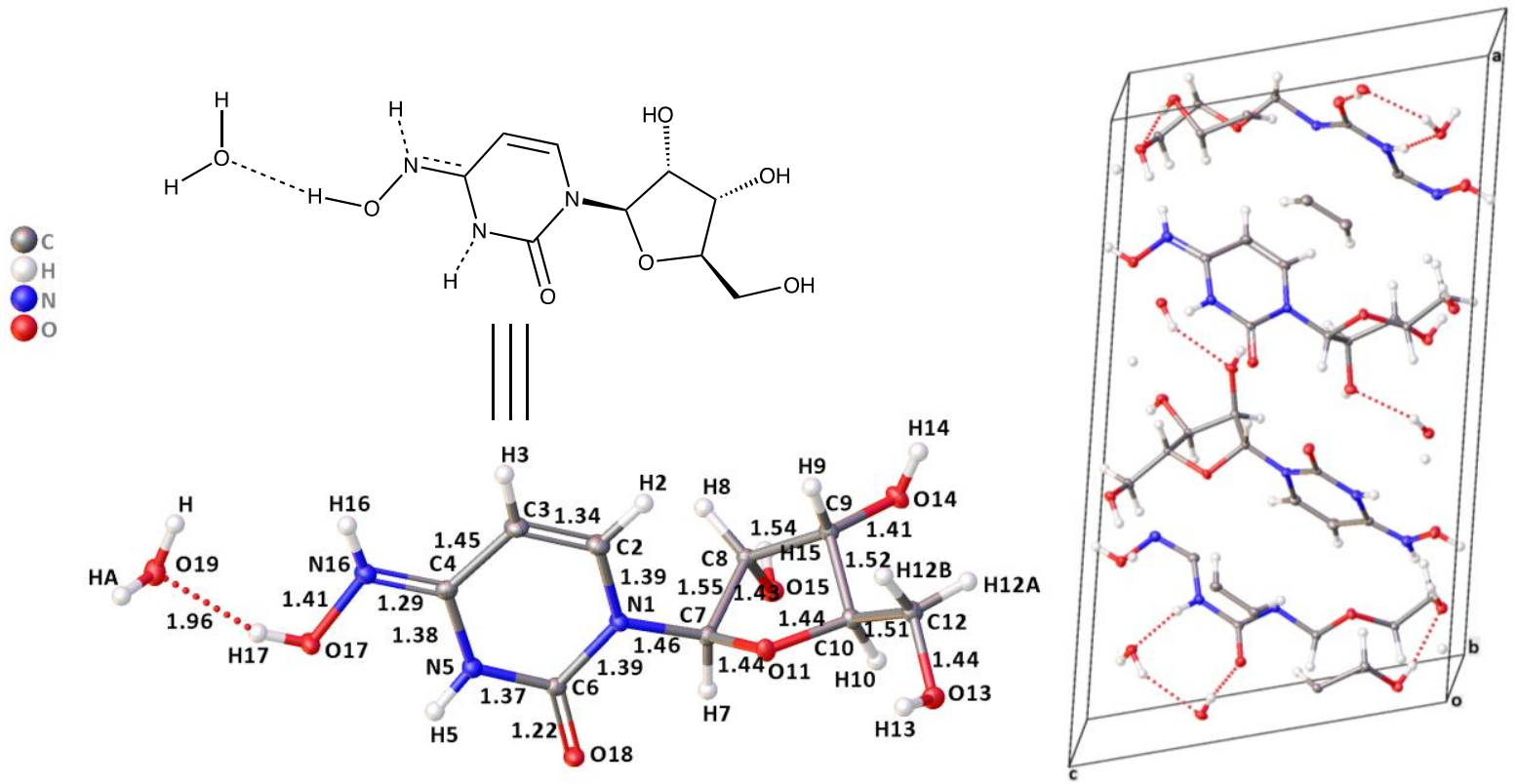

The crystal structure obtained by recrystallization of NHC in water showed that a single hydrogen atom occupied two positions at $\mathrm{H} 5$ and $\mathrm{H} 16$ in the ratio 76.33 : 23.67 respectively. This confirmed that the NHC is present in two forms (tautomers). Surprisingly, the crystal structure also showed NHC adduct with one water molecule. One water molecule showed four hydrogen banding with four free hydroxy groups of NHC.

\section{Crystal structure of NHC (recrystallized from DMF):}

CCDC No.: 2044295 


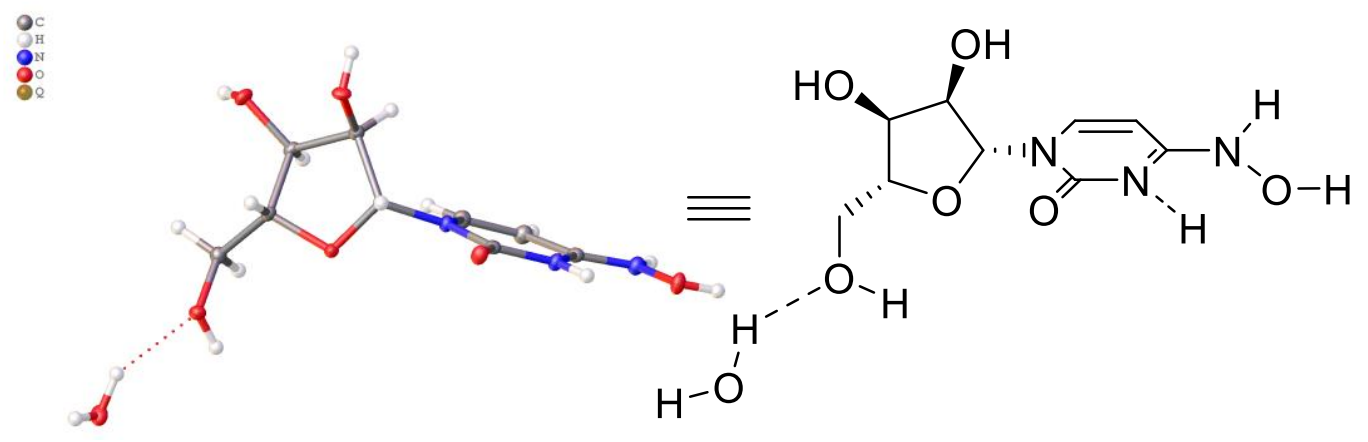

Then NHC was recrystallized from anhydrous DMF and collected single crystal structure with the help of $\mathrm{X}$-ray crystallography. And again, NHC showed adduct with one water molecule. The tautomeric ratio was $82: 18$.

\section{Karl-Fischer data for NHC:}

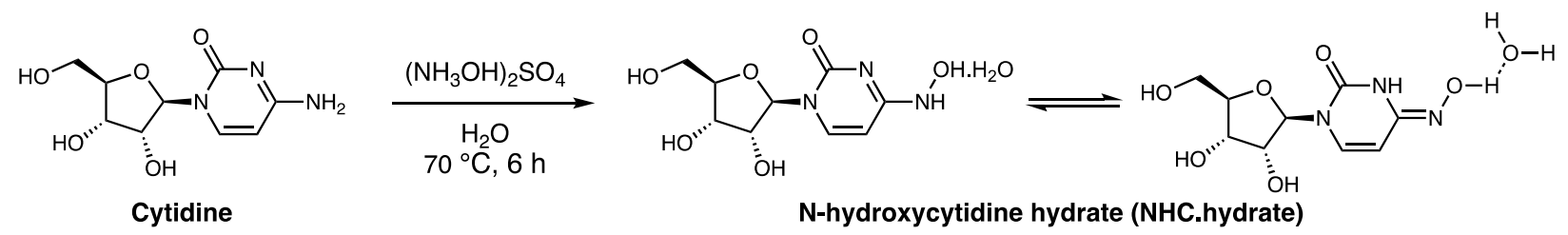

Molecular Weight of $\mathrm{NHC} 1 \mathrm{H}_{2} \mathrm{O}=277.09$

Molecular Weight of $\mathrm{H}_{2} \mathrm{O}=18.01$

$\mathrm{H}_{2} \mathrm{O} \%$ in $\mathrm{NHC} .1 \mathrm{H}_{2} \mathrm{O}=6.5 \%$ (Theoretically)

\begin{tabular}{|c|c|c|c|}
\hline Entry & $\begin{array}{c}\text { Amount of } \\
\mathbf{N H C . 1 H}_{2} \mathbf{O}\end{array}$ & $\begin{array}{c}\text { Amount of } \mathbf{H}_{2} \mathbf{O} \\
\text { (KF reading) }\end{array}$ & $\begin{array}{c}\text { Amount of } \mathbf{H}_{2} \mathbf{O} \\
\text { present in sample }\end{array}$ \\
\hline 1 & $63.0 \mathrm{mg}$ & $4.211 \mathrm{mg}$ & $6.684 \%$ \\
\hline 2 & $62.0 \mathrm{mg}$ & $4.135 \mathrm{mg}$ & $6.669 \%$ \\
\hline 3 & $109.0 \mathrm{mg}$ & $7.290 \mathrm{mg}$ & $6.688 \%$ \\
\hline
\end{tabular}

Theoretically, if $\mathrm{NHC}$ is associated with one water molecule, $\mathrm{NHC} \cdot 1 \mathrm{H}_{2} \mathrm{O}$ should contain $6.5 \%$. The KarlFischer data showed $6.68 \%$ (average) water present in samples, which was just $0.12 \%$ extra than theoretical value. This experiment confirmed the association of water molecules with NHC and $N$-hydroxycytidine is actually a $N$-hydroxycytidine.hydrate.

Now, since the molecular weight of NHC was increased from 259.08 (NHC) to 277.09 ( $\mathrm{NHC} 1 \mathrm{H}_{2} \mathrm{O}$ ), its purities have increased from $93-94 \%$ to $99-100 \%$ by qNMR. 


\section{Scale-Up of $N$-Hydroxycytidine Hydrate:}

Table S3: Scale-up reactions for $N$-hydroxycytidine hydrate $\left(\mathrm{NHC}_{1} 1 \mathrm{H}_{2} \mathrm{O}\right)$.

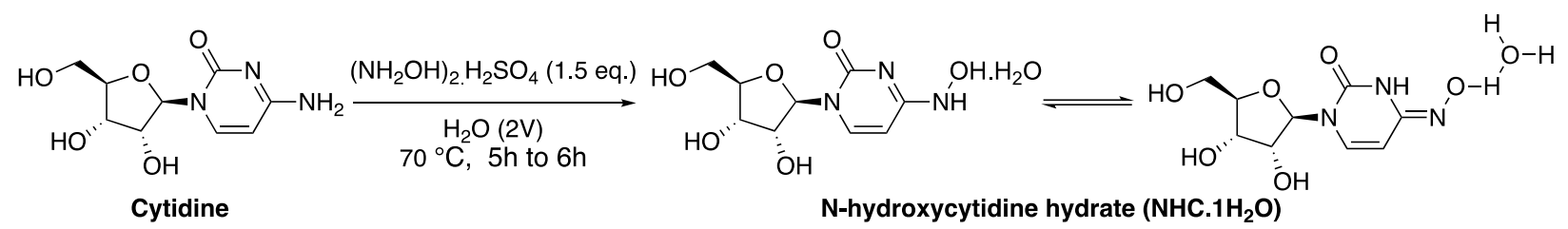

\begin{tabular}{|c|c|c|c|c|c|c|c|c|}
\hline Entry & Scale & $\begin{array}{c}\text { RB flask } \\
\text { size }\end{array}$ & $\begin{array}{c}\text { Reaction } \\
\text { time }\end{array}$ & $\begin{array}{c}\text { LCAP } \\
\text { (cytidine } \\
\text { /NHC/uridine) }\end{array}$ & $\begin{array}{c}\text { Mass of } \\
\text { product } \\
(\mathbf{g})\end{array}$ & LCAP & $\begin{array}{c}\text { Purity by } \\
\text { qNMR } \\
(\%)\end{array}$ & $\begin{array}{c}\text { Yield \% } \\
\text { (adjusted with } \\
\text { qNMR purity })\end{array}$ \\
\hline 1 & $5 \mathrm{~g}$ & $50 \mathrm{~mL}$ & $5 \mathrm{~h}$ & $4.5 / 93.5 / 2.0$ & 4.85 & 99.6 & 100 & 84 \\
\hline 2 & $10 \mathrm{~g}$ & $50 \mathrm{~mL}$ & $5 \mathrm{~h}$ & $7.6 / 88.3 / 4.1$ & 9.631 & 99.7 & 100 & 85 \\
\hline 3 & $50 \mathrm{~g}$ & $250 \mathrm{~mL}$ & $6 \mathrm{~h}$ & $6.7 / 87.9 / 5.4$ & 47.130 & 100 & 99 & 83 \\
\hline 4 & $200 \mathrm{~g}$ & $1000 \mathrm{~mL}$ & $6 \mathrm{~h}$ & $4.4 / 92.5 / 3.1$ & 192.31 & 100 & 100 & 85 \\
\hline 5 & $500 \mathrm{~g}$ & $2000 \mathrm{~mL}$ & $5 \mathrm{~h}$ & $3.9 / 93.3 / 1.8$ & 477.09 & 100 & 100 & 84 \\
\hline
\end{tabular}

With optimized reaction conditions at $1 \mathrm{~g}$ scale, the process was scaled up. The reactions at $5 \mathrm{~g}, 10 \mathrm{~g}, 50 \mathrm{~g}$, $200 \mathrm{~g}$ and $0.5 \mathrm{Kg}$ worked smoothly without any scale up issues and successfully provided $83 \%$ to $85 \%$ product (100 A\% by HPLC and $100 \mathrm{wt} \%$ by qNMR).

Images for $50 \mathrm{~g}$ reaction:

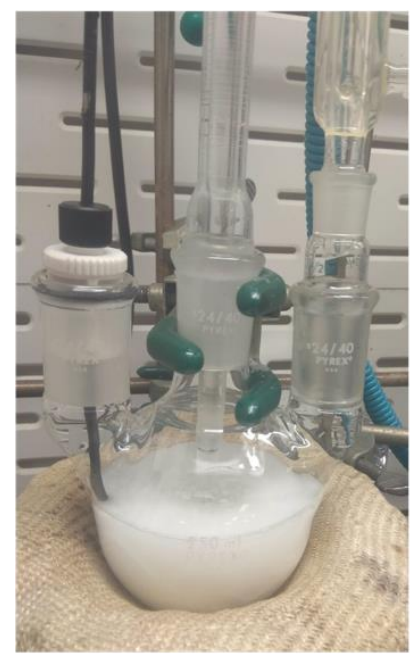

Before heating

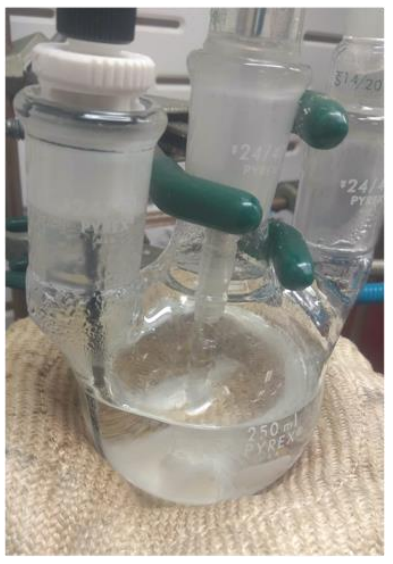

After 10 minutes

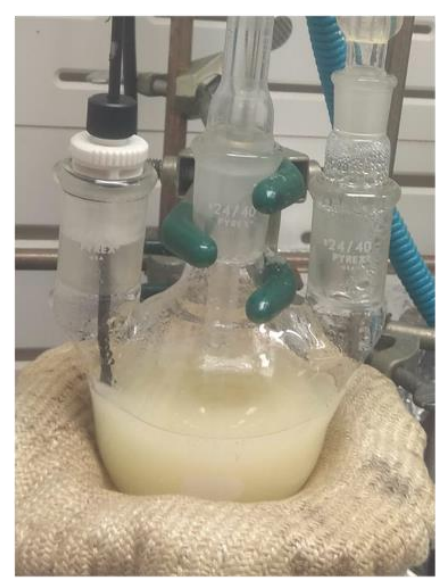

After $2 h$
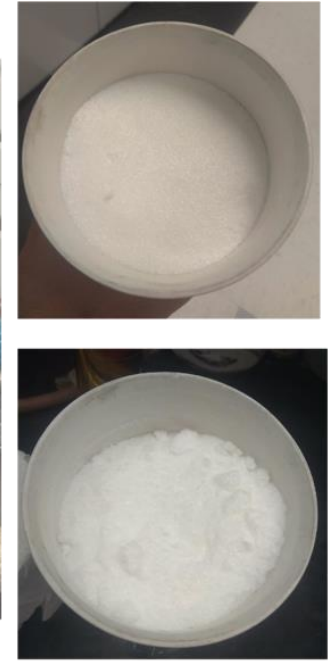

Product obtained from reaction mixture 
Images for $0.5 \mathrm{Kg}$ reaction:

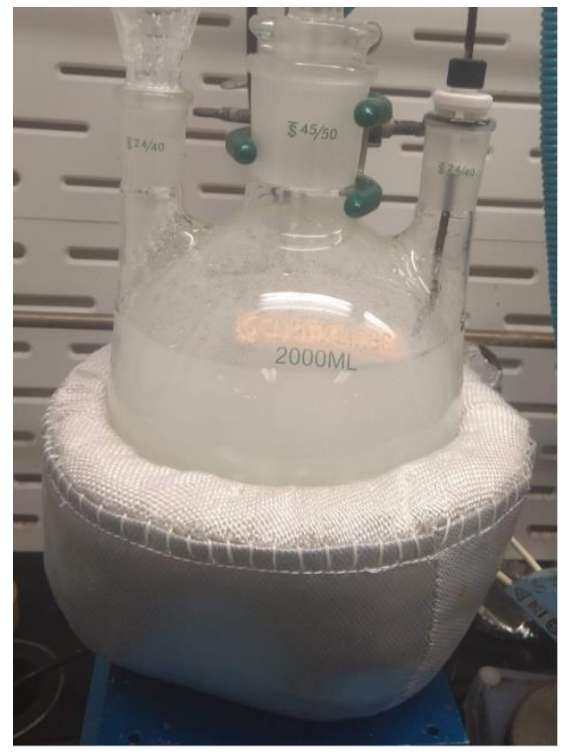

Before heating

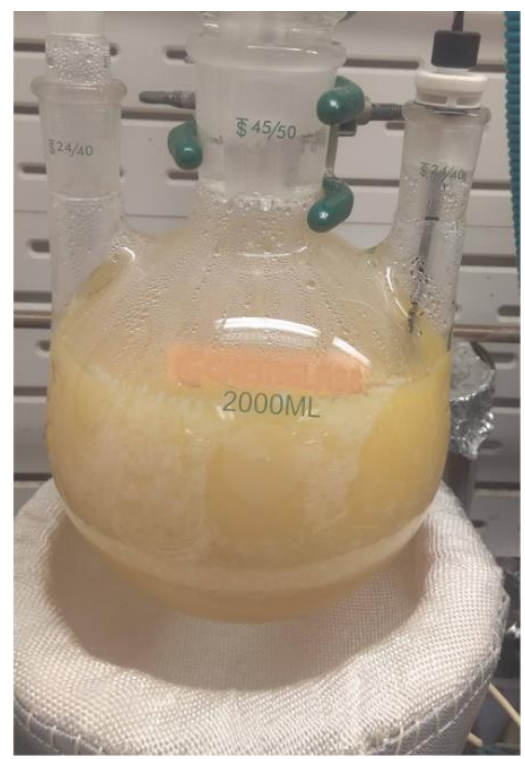

Before filtration

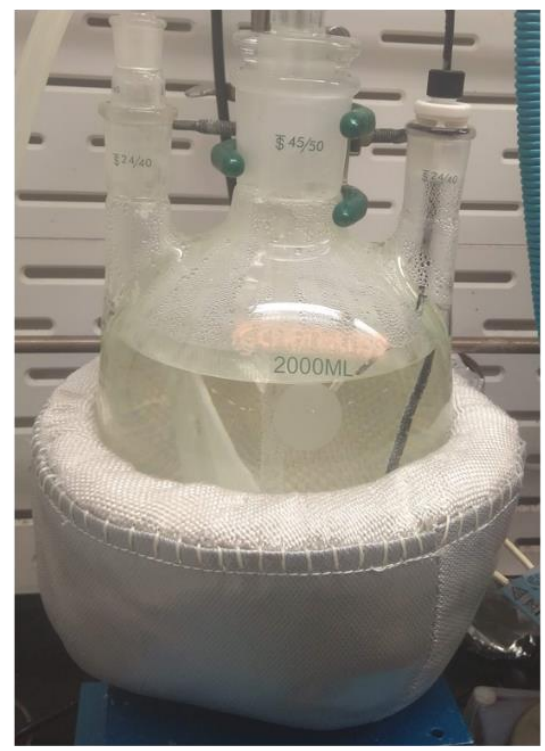

After 10 minutes

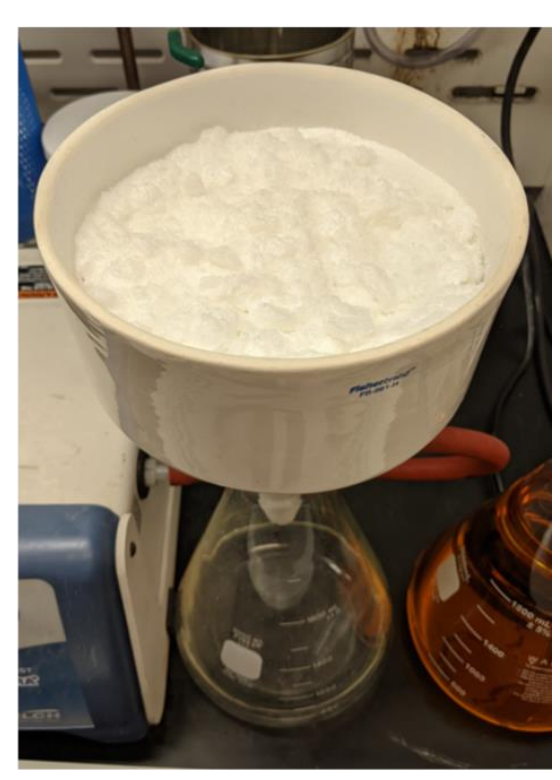
After filtration

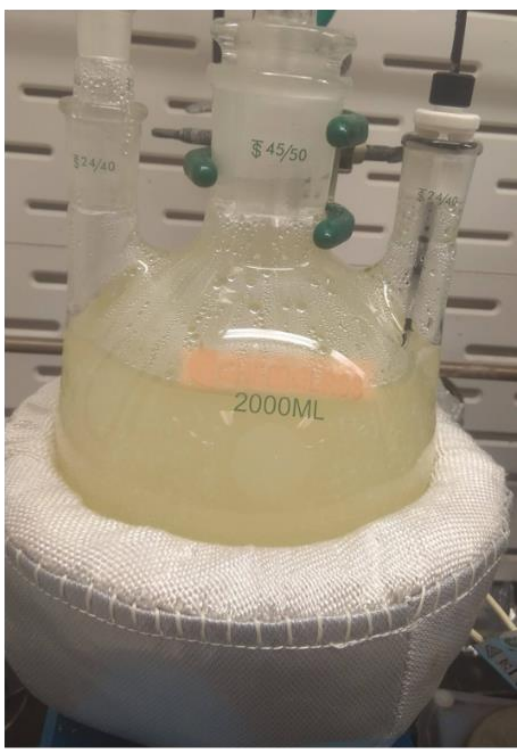

After $1 \mathrm{~h}$

After filtration 


\section{Enzymatic acylation of $N$-hydroxycytidine hydrate $\left(\mathrm{NHC}^{\left.-1 \mathrm{H}_{2} \mathrm{O}\right)}\right.$ :}

\section{Reaction Optimization and Impurity Profile:}

Table S4: The reaction optimization with different enzymes and solvents

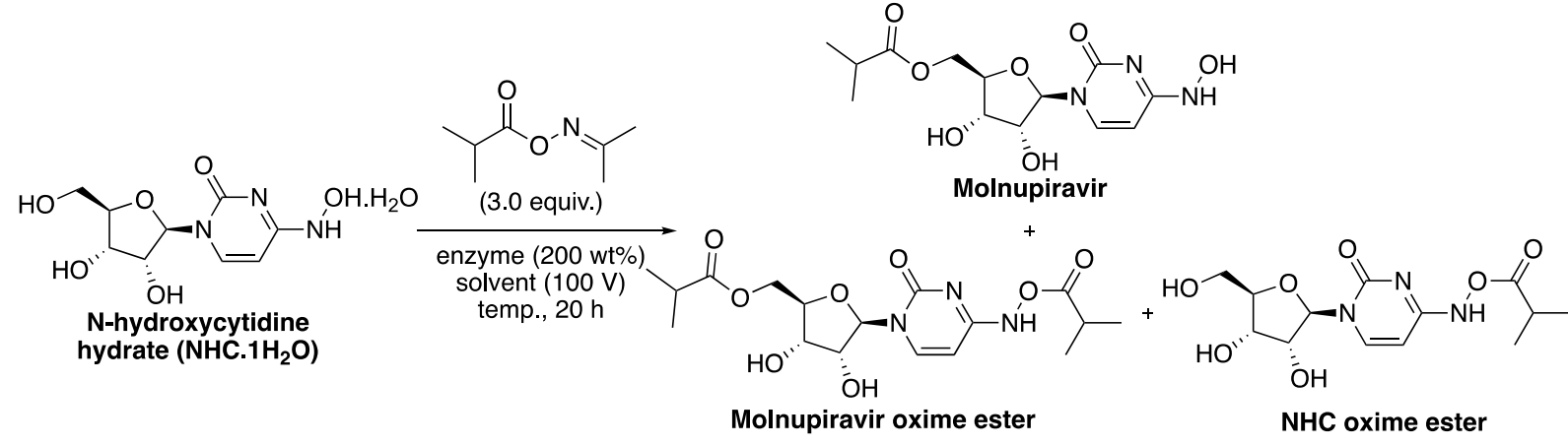

\begin{tabular}{|c|c|c|c|c|c|c|c|c|c|c|c|}
\hline \multirow{3}{*}{ Entry } & \multirow{3}{*}{ Enzyme } & \multicolumn{10}{|c|}{ LCAP (NHC/ molnupiravir/ molnupiravir oxime ester/ NHC oxime ester) } \\
\hline & & \multicolumn{2}{|c|}{ 1,4-Dioxane } & \multicolumn{2}{|c|}{$\mathrm{THF}$} & \multicolumn{2}{|c|}{ 2-MeTHF } & \multicolumn{2}{|c|}{$\mathrm{CH}_{3} \mathrm{CN}$} & \multicolumn{2}{|c|}{ DMF } \\
\hline & & $30^{\circ} \mathrm{C}$ & $60^{\circ} \mathrm{C}$ & $30^{\circ} \mathrm{C}$ & $60{ }^{\circ} \mathrm{C}$ & $30^{\circ} \mathrm{C}$ & $60{ }^{\circ} \mathrm{C}$ & $30^{\circ} \mathrm{C}$ & $60{ }^{\circ} \mathrm{C}$ & $30^{\circ} \mathrm{C}$ & $60{ }^{\circ} \mathrm{C}$ \\
\hline & - & - & $89 / 0 / 0 / 9$ & - & $79 / 0 / 0 / 17$ & - & $86 / 0 / 0 / 13$ & - & $93 / 0 / 0 / 6$ & - & - \\
\hline 1 & Enz-1 & $95 / 1 / 0 / 4$ & $74 / 2 / 0 / 21$ & $93 / 1 / 0 / 5$ & $69 / 1 / 0 / 23$ & $95 / 1 / 0 / 3$ & $72 / 3 / 0 / 20$ & $95 / 0 / 0 / 5$ & $76 / 1 / 0 / 19$ & $96 / 0 / 0 / 3$ & $91 / 0 / 0 / 8$ \\
\hline 2 & Enz-2 & $10 / 86 / 4 / 1$ & $11 / 82 / 5 / 1$ & $6 / 81 / 11 / 1$ & $7 / 81 / 11 / 1$ & $28 / 68 / 2 / 1$ & $18 / 75 / 4 / 2$ & $5 / 67 / 27 / 2$ & $8 / 68 / 22 / 2$ & $97 / 0 / 0 / 2$ & $86 / 0 / 0 / 10$ \\
\hline 3 & Enz-3 & $94 / 1 / 0 / 4$ & $78 / 1 / 0 / 17$ & $94 / 0 / 0 / 1$ & $69 / 4 / 1 / 21$ & $85 / 2 / 0 / 12$ & $66 / 4 / 1 / 23$ & $93 / 0 / 0 / 5$ & $75 / 2 / 1 / 20$ & $96 / 0 / 0 / 2$ & $92 / 0 / 0 / 5$ \\
\hline 4 & Enz-4 & $88 / 5 / 0 / 8$ & $56 / 7 / 1 / 32$ & $85 / 4 / 0 / 10$ & $52 / 12 / 2 / 27$ & $85 / 2 / 1 / 7$ & $48 / 14 / 2 / 16$ & $90 / 1 / 0 / 7$ & $56 / 5 / 3 / 24$ & $96 / 0 / 0 / 3$ & $89 / 0 / 0 / 10$ \\
\hline 5 & Enz-5 & $95 / 0 / 0 / 5$ & - & - & - & - & - & - & - & - & - \\
\hline 6 & Enz-6 & $94 / 0 / 0 / 4$ & - & - & - & - & - & - & - & - & - \\
\hline 7 & Enz-7 & $94 / 0 / 0 / 4$ & - & - & - & - & - & - & - & - & - \\
\hline 8 & Enz-8 & $92 / 0 / 0 / 0$ & $80 / 0 / 0 / 16$ & - & $75 / 0 / 0 / 16$ & - & $81 / 0 / 5 / 18$ & - & $77 / 0 / 0 / 21$ & - & $92 / 0 / 0 / 5$ \\
\hline 9 & Enz-9 & $35 / 33 / 13 / 18$ & - & $29 / 41 / 14 / 12$ & - & $10 / 72 / 12 / 2$ & - & $59 / 16 / 8 / 14$ & - & $95 / 0 / 0 / 1$ & - \\
\hline $10^{b}$ & Enz-9 & - & - & $15 / 61 / 16 / 5$ & - & $4 / 77 / 13 / 1$ & - & $26 / 34 / 19 / 17$ & - & $94 / 0 / 0 / 2$ & - \\
\hline $11^{c}$ & Enz-9 & $36 / 36 / 10 / 11$ & - & $23 / 51 / 12 / 6$ & - & - & - & - & - & - & - \\
\hline $12^{d}$ & Enz-9 & $42 / 43 / 2 / 2$ & - & $22 / 58 / 5 / 2$ & - & - & - & - & - & - & - \\
\hline 13 & Enz-10 & $34 / 59 / 4 / 2$ & - & $28 / 61 / 7 / 4$ & - & $53 / 45 / 1 / 1$ & - & $37 / 44 / 13$ & - & $97 / 0 / 0 / 2$ & - \\
\hline $14^{e}$ & Enz-11 & $7 / 76 / 8 / 0$ & $20 / 65 / 2 / 0$ & $5 / 74 / 13 / 0$ & $18 / 67 / 3 / 1$ & $22 / 65 / 9 / 0$ & $20 / 60 / 4 / 0$ & $9 / 67 / 15 / 2$ & $8 / 62 / 19 / 3$ & $83 / 7 / 0 / 2$ & $87 / 0 / 0 / 4$ \\
\hline
\end{tabular}

${ }^{a}$ Reaction conditions: $N$-hydroxycytidine hydrate $(25 \mathrm{mg})$, enzyme (200 wt $\left.\%\right)$, solvent (100 V), temp. and 20h. ${ }^{b}$ Reaction was stirred for $48 \mathrm{~h} .{ }^{c} 400 \mathrm{wt} \%$ of enzyme was used. ${ }^{d} 800 \mathrm{wt} \%$ enzyme was used. ${ }^{e}$ Reactions were carried out at $40{ }^{\circ} \mathrm{C}$ instead of $30{ }^{\circ} \mathrm{C}$.

\section{Enzyme list:}

Enz1: Lipase, immoblilized on Immobead 150 from Pseudomonas fluorescens (600U/g, sigma Aldrich, Product code: $90678-10 \mathrm{G})$

Enz-2: Lipase B Candida antarctica immobilized on Immobead 150, recombinant from Aspergillus oryzaz ( $\geq 1800$ U/g, Sigma Aldrich, Product code: 54326-10G) 
Enz-3: Amano Lipase from Pseudomonas fluorescens (beige-brown, $\geq 20,000 \mathrm{U} / \mathrm{g}$, Sigma Aldrich, Product code: 534730-10G)

Enz-4: Amano Lipase PS, from Burkholderia cepacian ( $\geq 30,000 \mathrm{U} / \mathrm{g}$, Sigma aldrich, Product code: 534641-10G)

Enz-5: Lipase A Candida antarctica, recombinant from Aspergillus oryzae (powder, beige, 2 U/mg, Sigma aldrich, Product code: 62287- 50MG-F)

Enz-6: Lipase B Candida antarctica, recombinant from Aspergillus oryzae (powder, beige, 9 U/mg, Sigma aldrich, 62288-50MG-F)

Enz-7: Lipase from Pseudomonas cepacian; Synonym: PS Lipase, Triacylglycerol acylhydrolase, Triacylglycerol lipase (powder, light beige, $\geq 30$ U/mg; Sigma Aldrich, Product code: 62309$100 \mathrm{MG})$

Enz-8: Subtilisin A, Aqueous Solution (Spectrum chemicals, Catalog number: S1211-10ML)

Enz-9: Lipozyme® RM (275 IUN/g, Strem Chemicals, Catalog number: 06-3120)

Enz-10: Lipozyme® TL IM (250 IUN/g, Strem Chemicals, Catalog number: 06-3155)

Enz-11: Novozym® 435 (10000 PLU/g, Strem Chemicals, Catalog number: 06-3123)

Among all screened enzymes, enzyme 2 and enzyme 11 provided good LCAP for product. However, enzyme 11 (Novozyme-435; CALB) is relatively inexpensive and widely available in market. The 1,4dioxane and 2-methyl tetrahydrofuran, both solvents found suitable. In addition, the reaction provided good conversion at lower temperature.

Table S5: Effect of enzyme loading and solvent volumes on reaction.
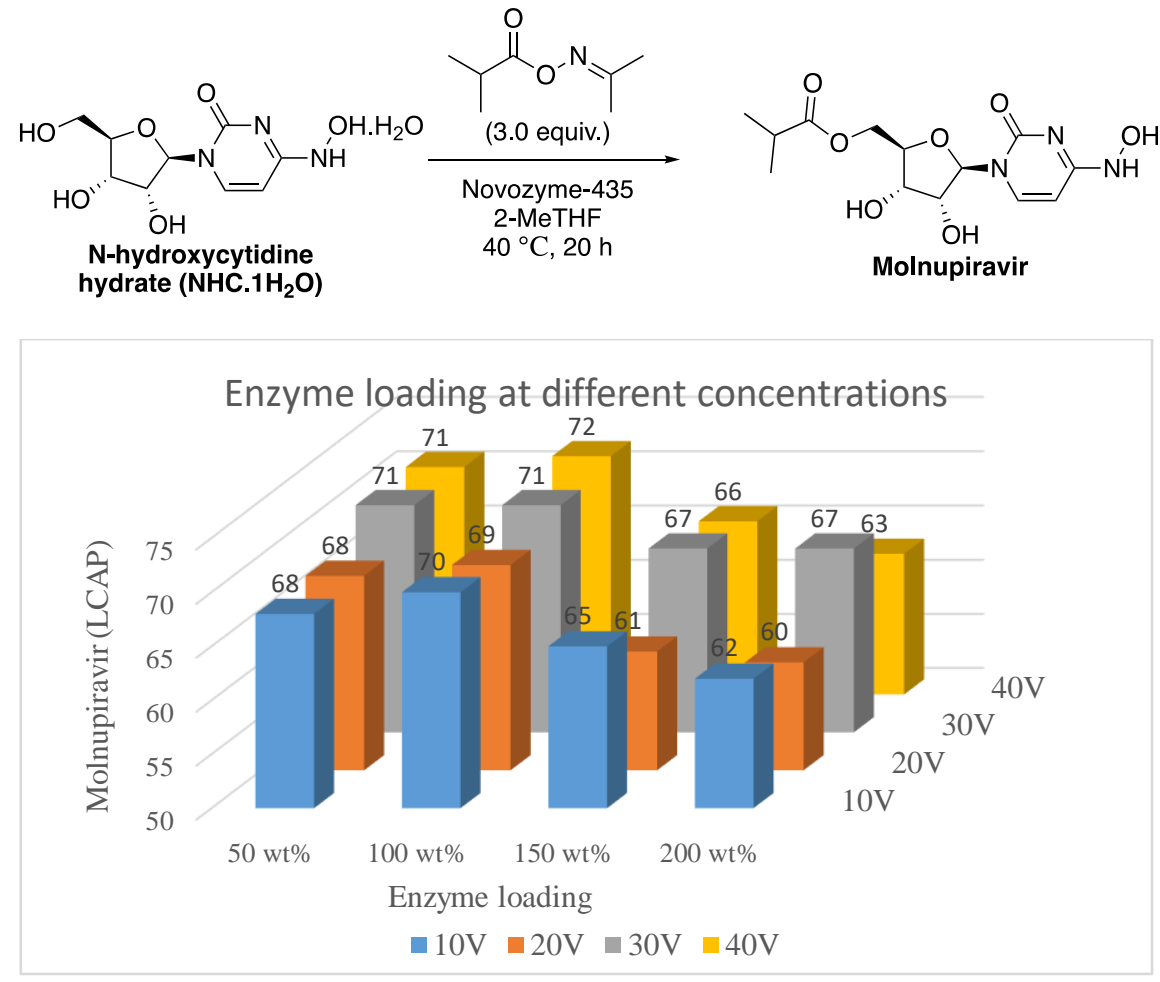
At first, the set of 16 reactions were carried out to understand the effect of enzyme loading at different concentrations. The reactions with low enzyme loading (50 wt \%) and at higher concentrations (10V) showed high product conversion and low molnupiravir oxime ester (diacylated product) formation.

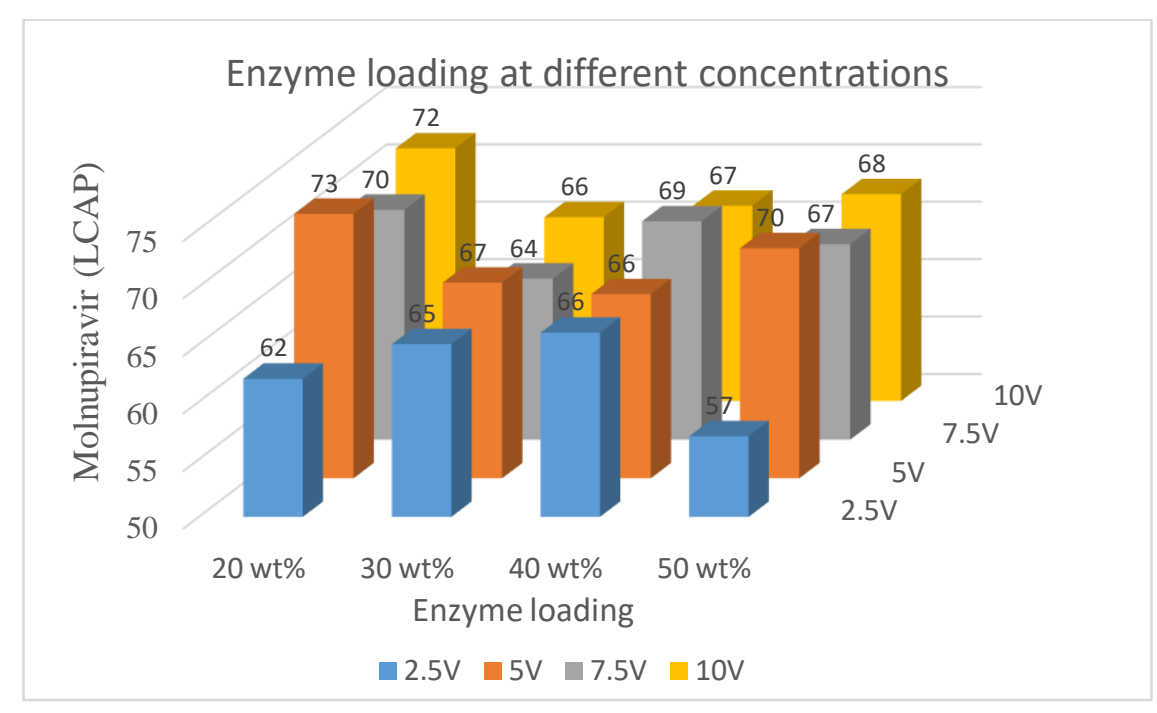

Next, the reactions were carried out with lower enzyme loading (up to $20 \mathrm{wt} \%$ ) and at higher concentrations (up to $2.5 \mathrm{~V}$ ). The reaction with $20 \mathrm{wt} \%$ enzyme loading in $5 \mathrm{~V}$ solvent provided best results among all.

\section{Reaction progress by time (200 wt\% enzyme and 50 Vol 2-MeTHF):}

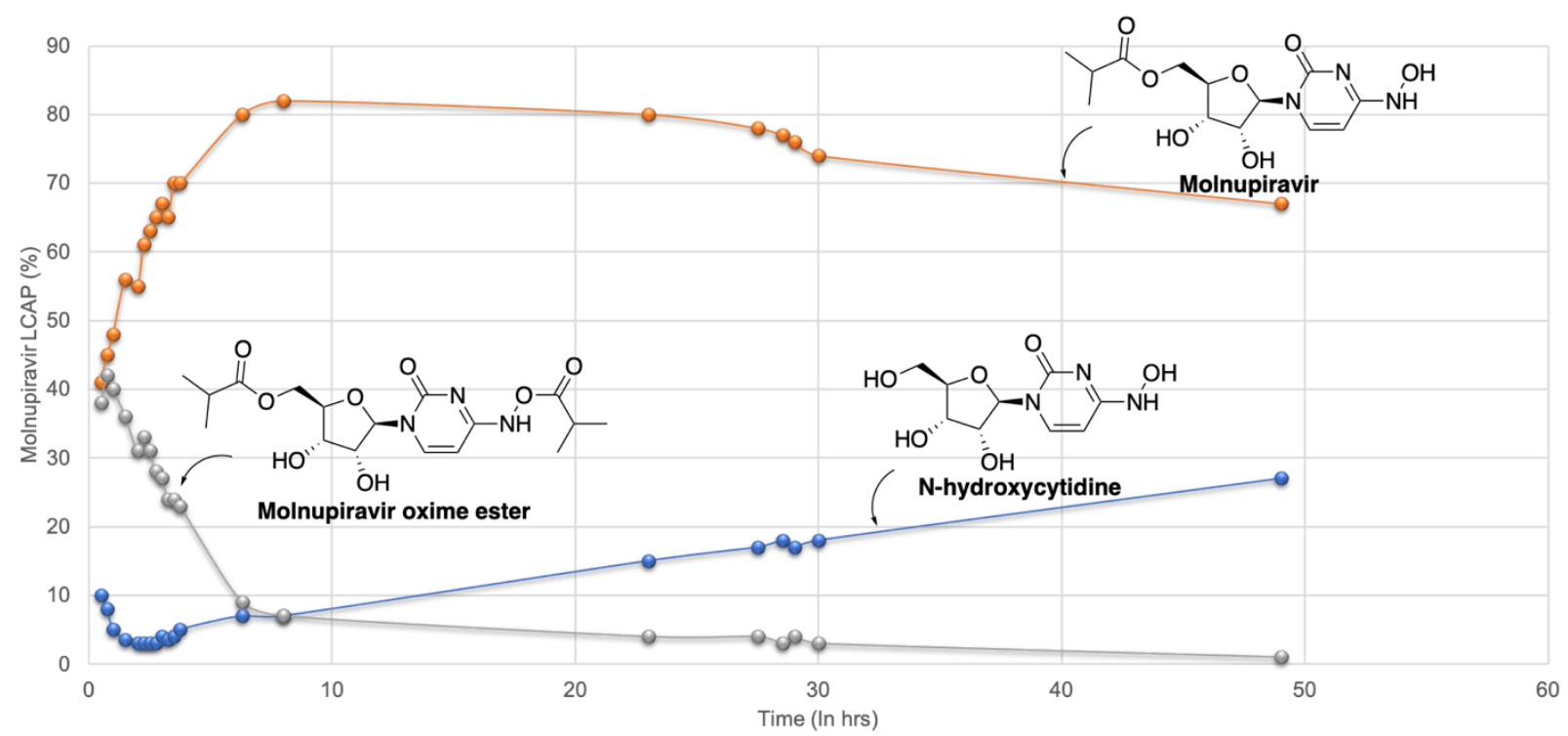


Reaction progress by time (20 wt\% enzyme and 5 Vol 2-MeTHF):

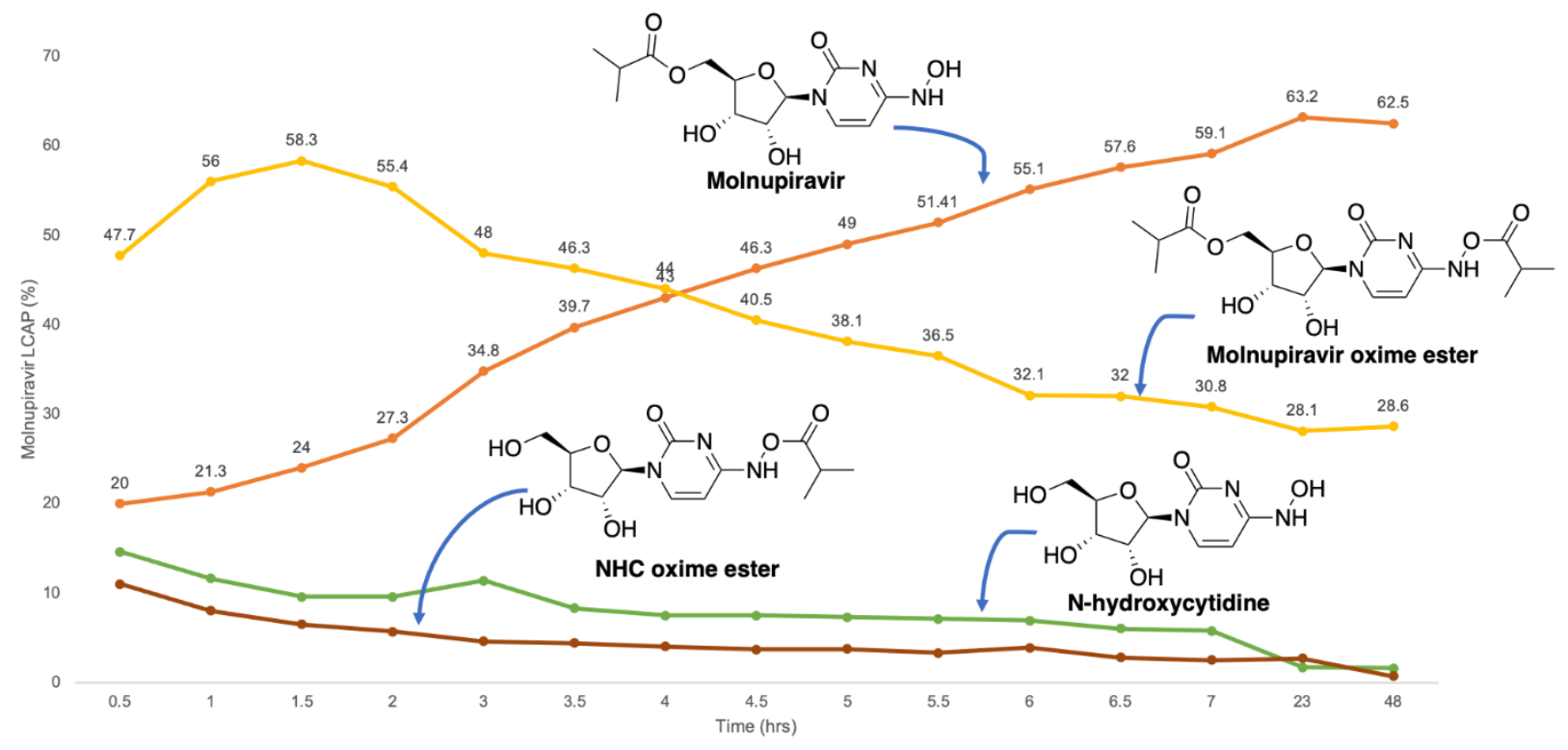

Control experiments to understand mechanism of product and impurities formation:

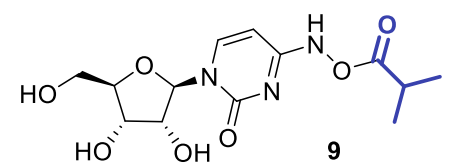

$\overbrace{}^{2}$

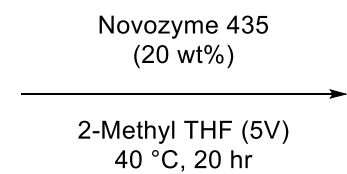

$40{ }^{\circ} \mathrm{C}, 20 \mathrm{hr}$<smiles>CC(C)C(=O)OC[C@H]1O[C@@H](n2ccc(NO)nc2=O)[C@H](O)[C@@H]1O</smiles>

$\begin{array}{ccc}\begin{array}{c}\text { 1, MK-4482 } \\ \text { (LCAP) }\end{array} & \begin{array}{c}\text { 7, NHC } \\ \text { (LCAP) }\end{array} & \begin{array}{c}\text { 4, Diacyl. } \\ \text { (LCAP) }\end{array} \\ 67 \% & 21 \% & 2 \%\end{array}$

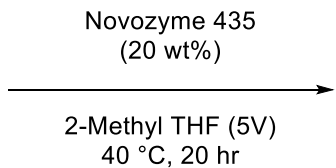<smiles>CC(C)C(=O)OCC1OC(n2ccc(NO)nc2=O)C(O)[C@@H]1O</smiles>

$\begin{array}{ccc}\begin{array}{c}\text { 1, MK-4482 } \\ \text { (LCAP) }\end{array} & \begin{array}{c}\text { 7, NHC } \\ \text { (LCAP) }\end{array} & \begin{array}{c}\text { 4, Diacyl. } \\ \text { (LCAP) }\end{array} \\ 75 \% & 14 \% & 0 \%\end{array}$ 


\section{Mechanistic Analysis and Purification:}

Table S6: Solvent screening for recrystallization of molnupiravir.

\begin{tabular}{|c|c|c|c|c|c|}
\hline & Solvent & RT & 50 C & Reflux & Return to RT \\
\hline 1 & Water & & & & \\
\hline 2 & MeOH & & & & \\
\hline 3 & EtOH & & & & \\
\hline 4 & IPA & & & & \\
\hline 5 & BuOH & & & & \\
\hline 6 & EtOAc & & & & \\
\hline 7 & iPrOAc & & & & \\
\hline 8 & Acetone & & & & \\
\hline 9 & Acetonitrile & & & & \\
\hline 10 & THF & & & & \\
\hline 11 & MTBE & & & & \\
\hline 12 & PhMe & & & & \\
\hline 13 & DCM & & & & \\
\hline 14 & Heptane & & & & \\
\hline & & & & & \\
\hline & Solution & & & & \\
\hline & Recristalized & & & & \\
\hline & & & & \\
\hline & & & & \\
\hline
\end{tabular}

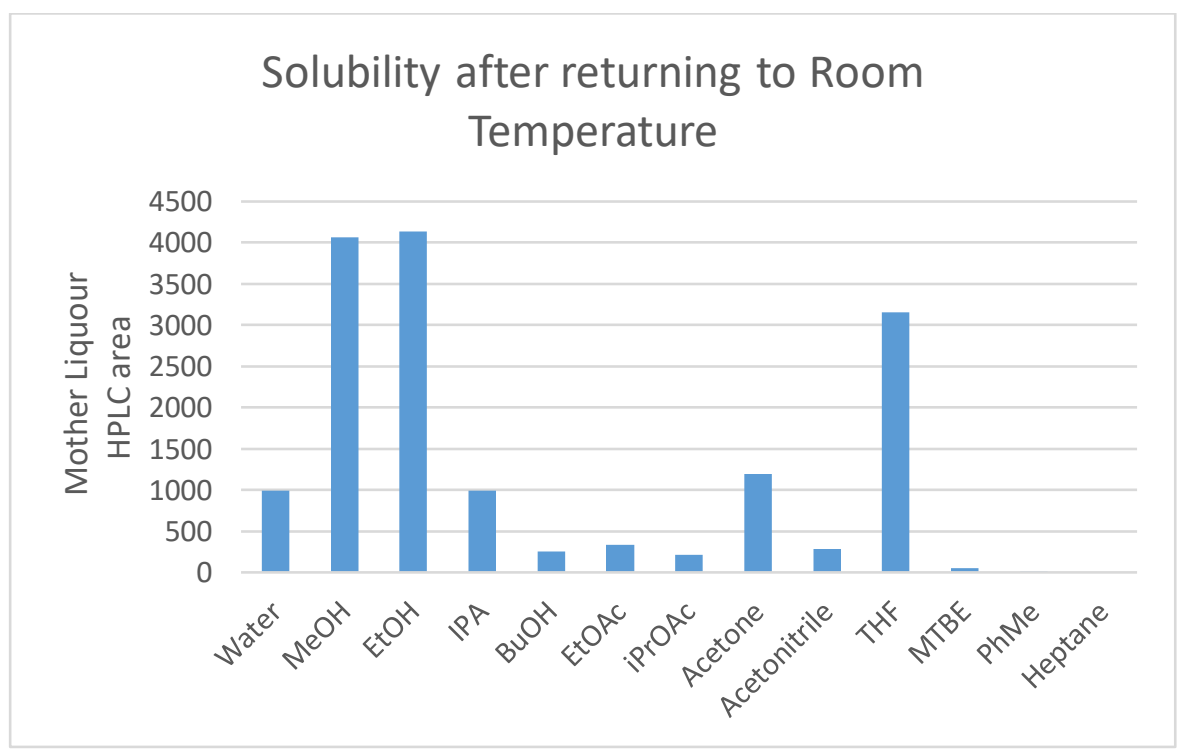

Among various solvents screened for recrystallization of molnupiravir, water, isopropanol, $n$-butanol, acetonitrile and ethyl acetate provided solid product after cooling. Acetonitrile and ethyl acetate were able to purge the molnupiravir oxime ester (diacylated product), however these solvents were unable to purge NHC. On the other hand, water was found as good solvent to purge NHC, but the recovery was low. 
Table S7: The optimization of reaction with different amount of acetone isobutyryl oxime ester.

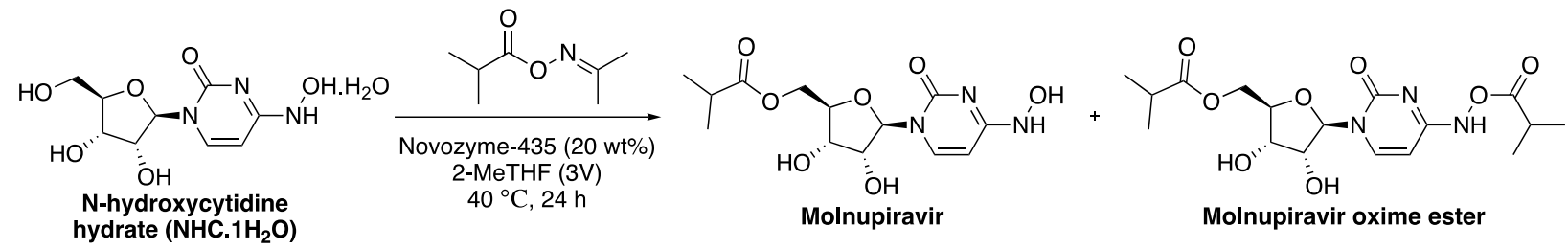

\begin{tabular}{|c|c|c|c|c|}
\hline \multirow{2}{*}{ Entry } & \multirow{2}{*}{$\begin{array}{c}\text { Acetone isobutyryl } \\
\text { oxime ester (equiv.) }\end{array}$} & \multicolumn{3}{|c|}{ LCAP } \\
\cline { 3 - 5 } & 1.0 & NHC & Molnupiravir & Molnupiravir oxime ester \\
\hline 1 & 1.5 & 24 & 61 & 3 \\
\hline 2 & 2.0 & 12 & 78 & 4 \\
\hline 3 & 2.5 & 6 & 73 & 4 \\
\hline 4 & 3.0 & 3 & 65 & 27 \\
\hline 5 & & & & \\
\hline
\end{tabular}

In order to reduce the formation of major side-product molnupiravir oxime ester (25\% to $30 \%$ ), the reaction was screened with lower amounts of acetone isobutyryl oxime ester. The reaction showed good LCAP for product $(78 \%)$ with 2.0 equiv. of reagent, however the unreacted NHC $(12 \%)$ was present in reaction mixture and difficult to purge from crude product. Considering this fact, we went ahead with the reaction condition where NHC consumption was higher.

Table S8: Recrystallization of molnupiravir from water to purge $\mathrm{NHC}^{a}$

\begin{tabular}{|c|c|c|c|c|c|c|}
\hline \multirow{2}{*}{ Entry } & \multirow{2}{*}{$\mathrm{H}_{2} \mathrm{O}$} & \multirow{2}{*}{$\begin{array}{l}\text { Cooling } \\
\text { condition }\end{array}$} & \multicolumn{2}{|c|}{$\begin{array}{l}\text { LCAP (NHC/molnupiravir/molnupiravir } \\
\text { oxime ester) }\end{array}$} & \multirow{2}{*}{$\begin{array}{l}\text { Recovered } \\
\text { molnupiravir }\end{array}$} & \multirow{2}{*}{$\begin{array}{l}\text { Molnupiravir } \\
\text { in mother } \\
\text { liquor }\end{array}$} \\
\hline & & & Recovered molnupiravir & Mother liquor & & \\
\hline 1 & $2.5 \mathrm{~V}$ & $20^{\circ} \mathrm{C}$ & $0.7 / 97.9 / 0$ & $14.3 / 78.6 / 6.4$ & $400 \mathrm{mg}(80 \%)$ & $86 \mathrm{mg}(17 \%)$ \\
\hline 2 & $5.0 \mathrm{~V}$ & $20^{\circ} \mathrm{C}$ & $0.6 / 99.1 / 0$ & $12.3 / 79.7 / 5.2$ & $301 \mathrm{mg}(60.2 \%)$ & $138 \mathrm{mg}(27.6 \%)$ \\
\hline 3 & $7.5 \mathrm{~V}$ & $20^{\circ} \mathrm{C}$ & $0.6 / 98.6 / 0$ & $8.5 / 85.5 / 3.5$ & $251 \mathrm{mg}(50.2 \%)$ & $189 \mathrm{mg}(37.8 \%)$ \\
\hline 4 & $2.5 \mathrm{~V}$ & $4{ }^{\circ} \mathrm{C}$ & $1.5 / 97.3 / 0.7$ & $16.8 / 73.1 / 5.8$ & $317 \mathrm{mg}(63 \%)$ & $61 \mathrm{mg}(12.2 \%)$ \\
\hline 5 & $5.0 \mathrm{~V}$ & $4{ }^{\circ} \mathrm{C}$ & $0.9 / 97.0 / 0.40$ & $12.6 / 77.7 / 4.8$ & $298 \mathrm{mg}(59.6 \%)$ & $104 \mathrm{mg}(20.8)$ \\
\hline 6 & $7.5 \mathrm{~V}$ & $4{ }^{\circ} \mathrm{C}$ & $0.7 / 98.0 / 0.3$ & $9.3 / 82.9 / 3.7$ & $299 \mathrm{mg}(60 \%)$ & $161 \mathrm{mg} \mathrm{(32 \% )}$ \\
\hline
\end{tabular}

${ }^{a}$ Reacrystallization conditions: Recrystallization was carried out on $500 \mathrm{mg}$ of crude material. The crude batch used for recrystallization showed LCAP as NHC (3.4), molnupiravir (93.3), molnupiravir oxime ester (1.7). 
Table S9: Optimization of hydrolysis of molnupiravir oxime ester to molnupiravir.

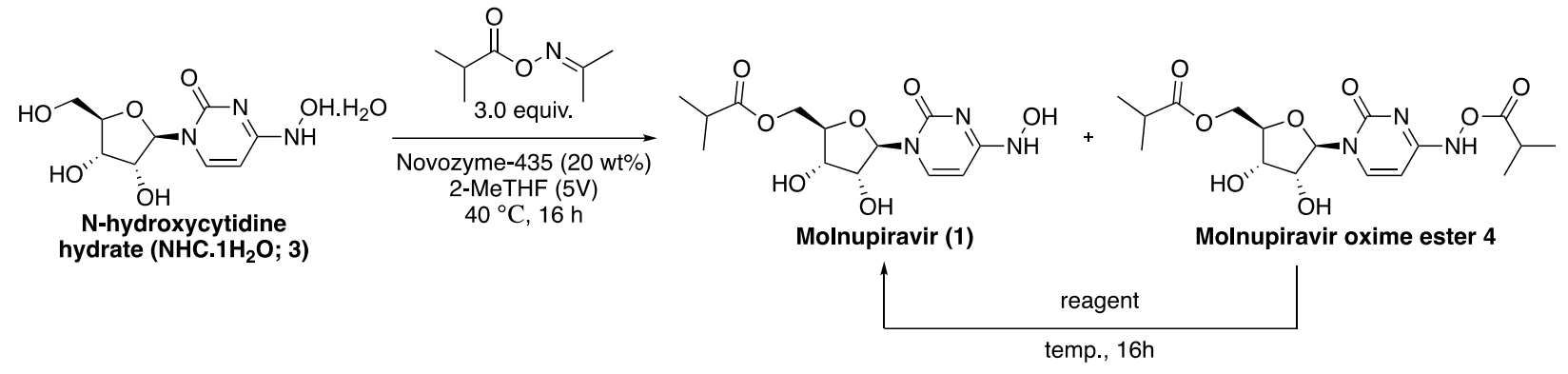

\begin{tabular}{|c|c|c|c|}
\hline \multirow{2}{*}{ Entry } & \multirow{2}{*}{ Reagent } & \multicolumn{2}{|c|}{ LCAP } \\
\cline { 3 - 4 } & & (NHC/molnupiravir/molnupiravir oxime ester) \\
\cline { 3 - 4 } & & $\mathbf{2 0}{ }^{\circ} \mathbf{C}$ & $\mathbf{6 0}^{\circ} \mathbf{C}$ \\
\hline 1 & -- (crude) & $3 / 70 / 20$ & - \\
\hline 2 & $\mathrm{H}_{2} \mathrm{O}$ & $3 / 71 / 19$ & $3 / 74 / 16$ \\
\hline 3 & $\mathrm{MeOH}$ & $3 / 70 / 19$ & $3 / 73 / 17$ \\
\hline 4 & $\mathrm{EtOH}$ & $4 / 69 / 19$ & $2 / 18 / 74$ \\
\hline 5 & $\mathrm{NH}_{3}$ in EtOH & $4 / 84 / 0$ & $6 / 88 / 5$ \\
\hline 6 & $\mathrm{NH}_{4} \mathrm{OH}$ (aq.) & $10 / 86 / 3$ & $55 / 43 / 0$ \\
\hline 7 & $\mathrm{NEt}$ & $3 / 72 / 7$ & $3 / 72 / 12$ \\
\hline 8 & $\mathrm{NH}_{2} \mathrm{OH}$ (aq.) & $4 / 92 / 1$ & - \\
\hline
\end{tabular}




\section{Scale-Up of Molnupiravir:}

Table S10: Scale-up reactions for molnupiravir.
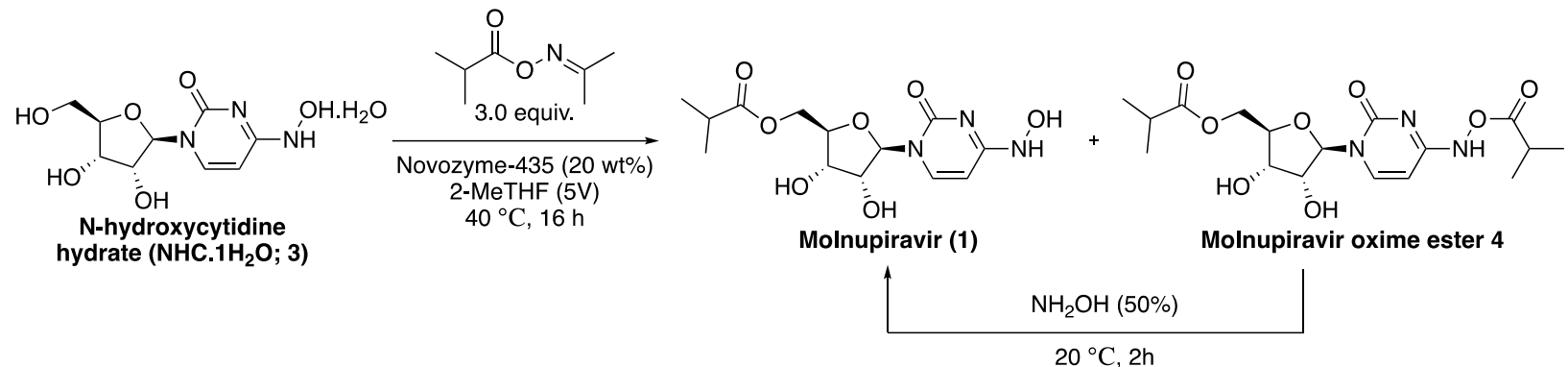

\begin{tabular}{|c|c|c|c|c|c|c|}
\hline Entry & Scale & $\begin{array}{c}\text { LCAP after } \\
\text { reaction }(\mathbf{3 , 1 , 4})\end{array}$ & $\begin{array}{c}\text { LCAP after } \\
\text { hydrolysis }(\mathbf{3 , 1 , 4 )}\end{array}$ & $\begin{array}{c}\text { LCAP after } \\
\text { recrystallization }\end{array}$ & $\begin{array}{c}\text { Purity by } \\
\text { qNMR (\%) }\end{array}$ & $\begin{array}{c}\text { Yield \% (adjusted } \\
\text { with qNMR purity) }\end{array}$ \\
\hline 1 & $10 \mathrm{~g}$ & $3.3 / 72.5 / 20.6$ & $3.0 / 91.1 / 2.5$ & 98.7 & 100 & 67 \\
\hline 2 & $50 \mathrm{~g}$ & $2.7 / 69.8 / 22 / 8$ & $3.7 / 90.5 / 2.8$ & 99.0 & 99.5 & 68 \\
\hline 3 & $100 \mathrm{~g}$ & $1.9 / 66.7 / 29.5$ & $2.9 / 91.7 / 3.0$ & 99.4 & 100 & 71 \\
\hline
\end{tabular}

Images for $100 \mathrm{~g}$ reaction:

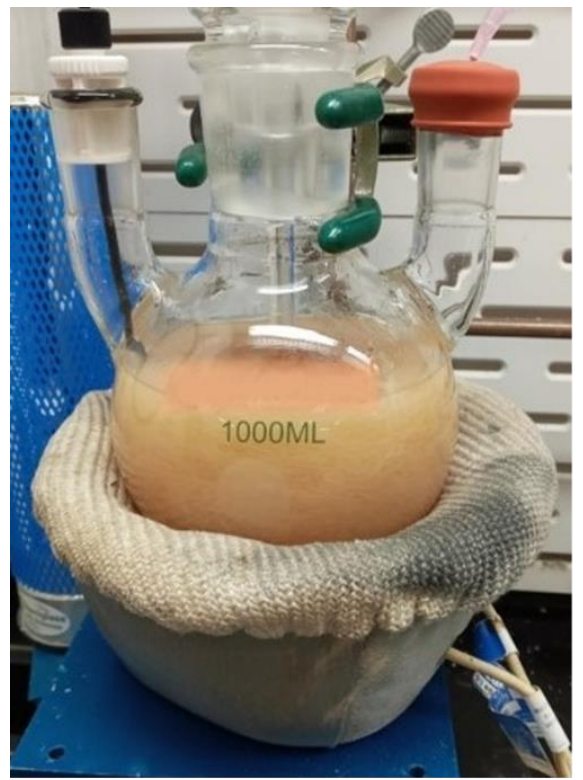

Before $\mathrm{NH}_{2} \mathrm{OH}$ treatment

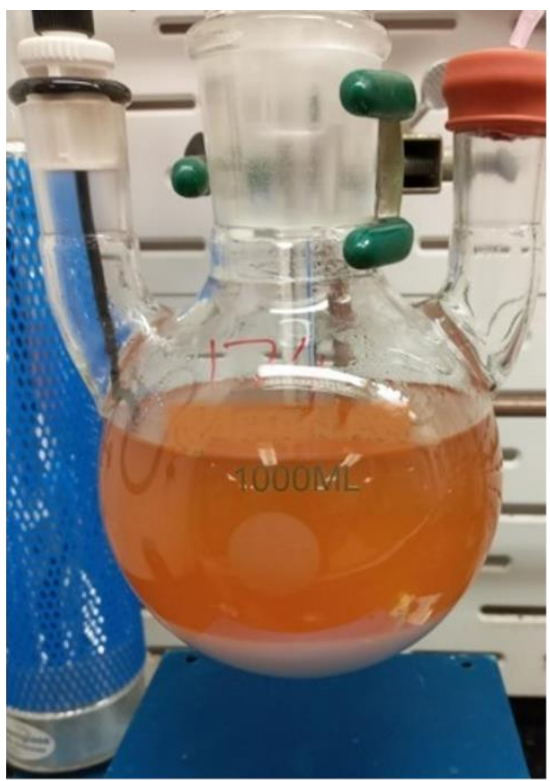

After $\mathrm{NH}_{2} \mathrm{OH}$ treatment 


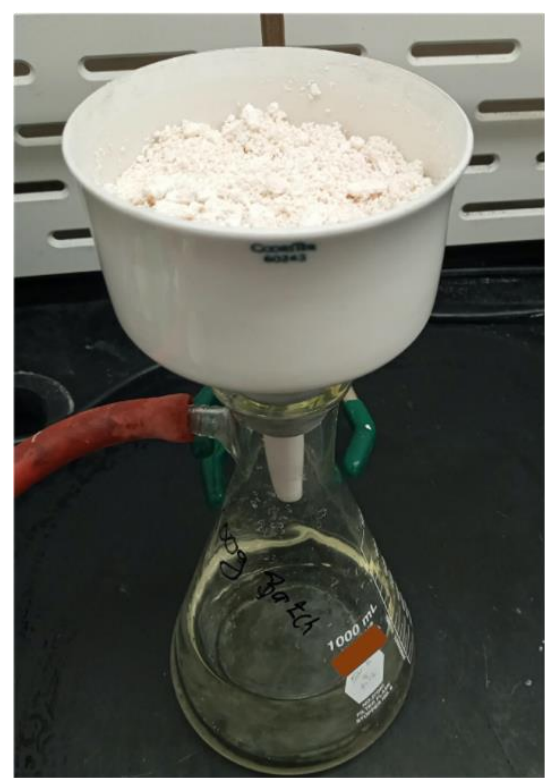

Molnupiravir After Recrystallization

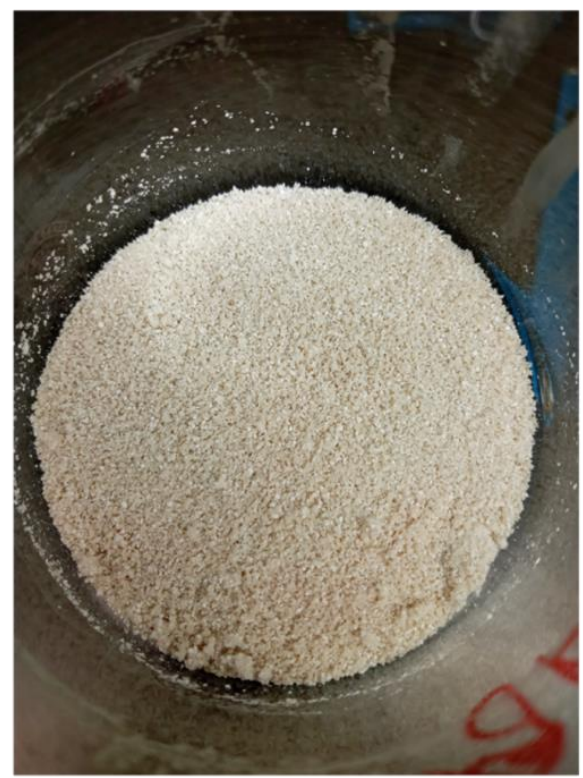

Recovered Enzyme 


\section{References:}

1. Vasudevan, N.; Ahlqvist, G. P.; McGeough, C. P.; Paymode, D. J.; Cardoso, F. S. P.; Lucas, T.; Dietz, J.-P.; Opatz, T.; Jamison, T. F.; Gupton, F. B.; Snead, D. R. A Concise Route to MK-4482 (EIDD-2801) from Cytidine, Chem. Commun., 2020, 56, 13363-13364.

2. Gopalsamuthiram, V.; Williams, C.; Noble, J.; Jamison, T. F.; Gupton, B. F.; Snead, D. R. A Concise Route to MK-4482 (EIDD-2801) from Cytidine: Part 2, Synlett, 2020, 32, 326328.

3. Purohit, M. K.; Poduch, E.; Wei, L. W.; Crandall, I. E.; To, T.; Kain, K. C.; Pai, E. F.; Kotra, L. P. Novel Cytidine-Based Orotidine-5'-Monophosphate Decarboxylase Inhibitors with an Unusual Twist, J. Med. Chem., 2012, 55, 9988-9997. 


\section{NMR spectra:}

${ }^{1} \mathrm{H}$ NMR Spectra of $N$-hydroxycytidine hydrate $\left(\mathrm{NHC}_{\mathbf{1}} 1 \mathrm{H}_{2} \mathrm{O}\right)$ in $\mathrm{CD}_{3} \mathrm{OD}$ at $600 \mathrm{MHz}$ :
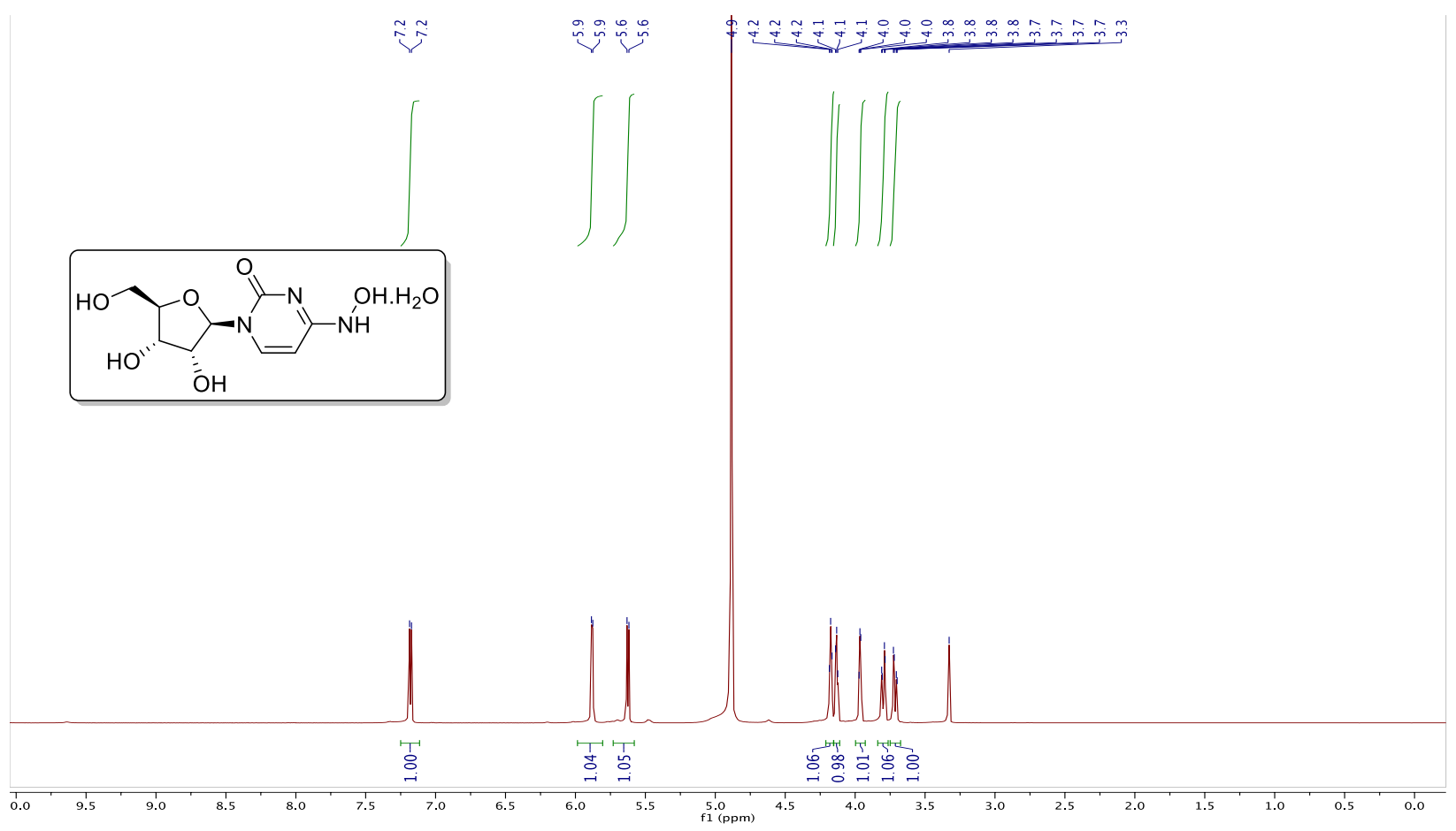

${ }^{13} \mathrm{C}$ NMR Spectra of $N$-hydroxycytidine hydrate $\left(\mathrm{NHC}^{1} \mathrm{H}_{2} \mathrm{O}\right)$ in $\mathrm{CD}_{3} \mathrm{OD}$ at $151 \mathrm{MHz}$ :

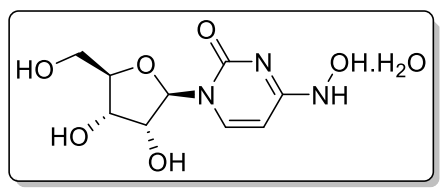

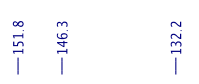
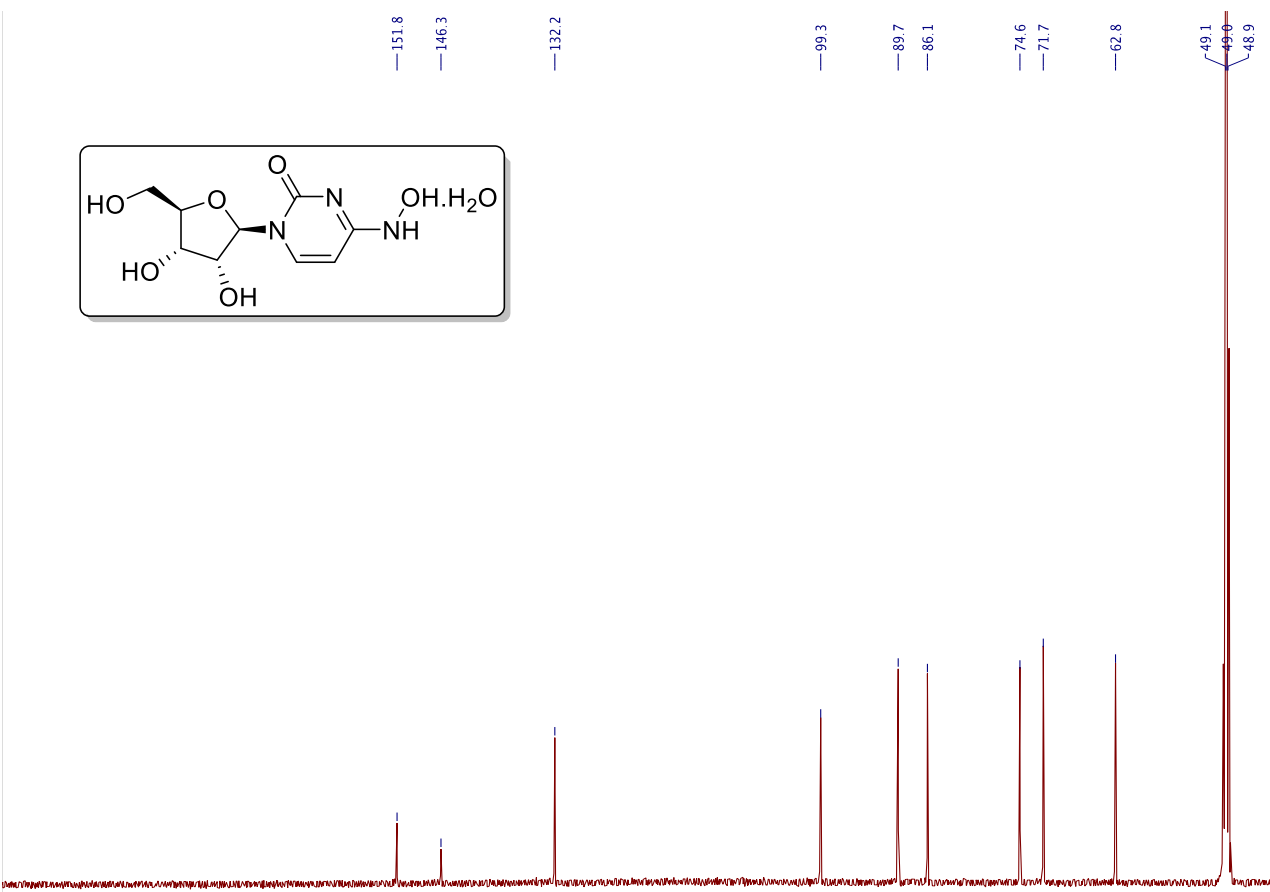

$$
\text { oo }
$$
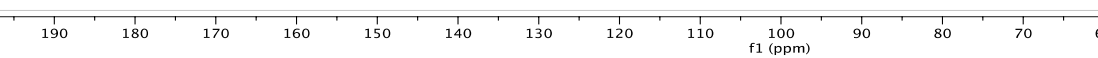
${ }^{1} \mathrm{H}$ NMR Spectra of $N$-hydroxycytidine oxime ester in $\mathrm{CD}_{3} \mathrm{OD}$ at $600 \mathrm{MHz}$ :

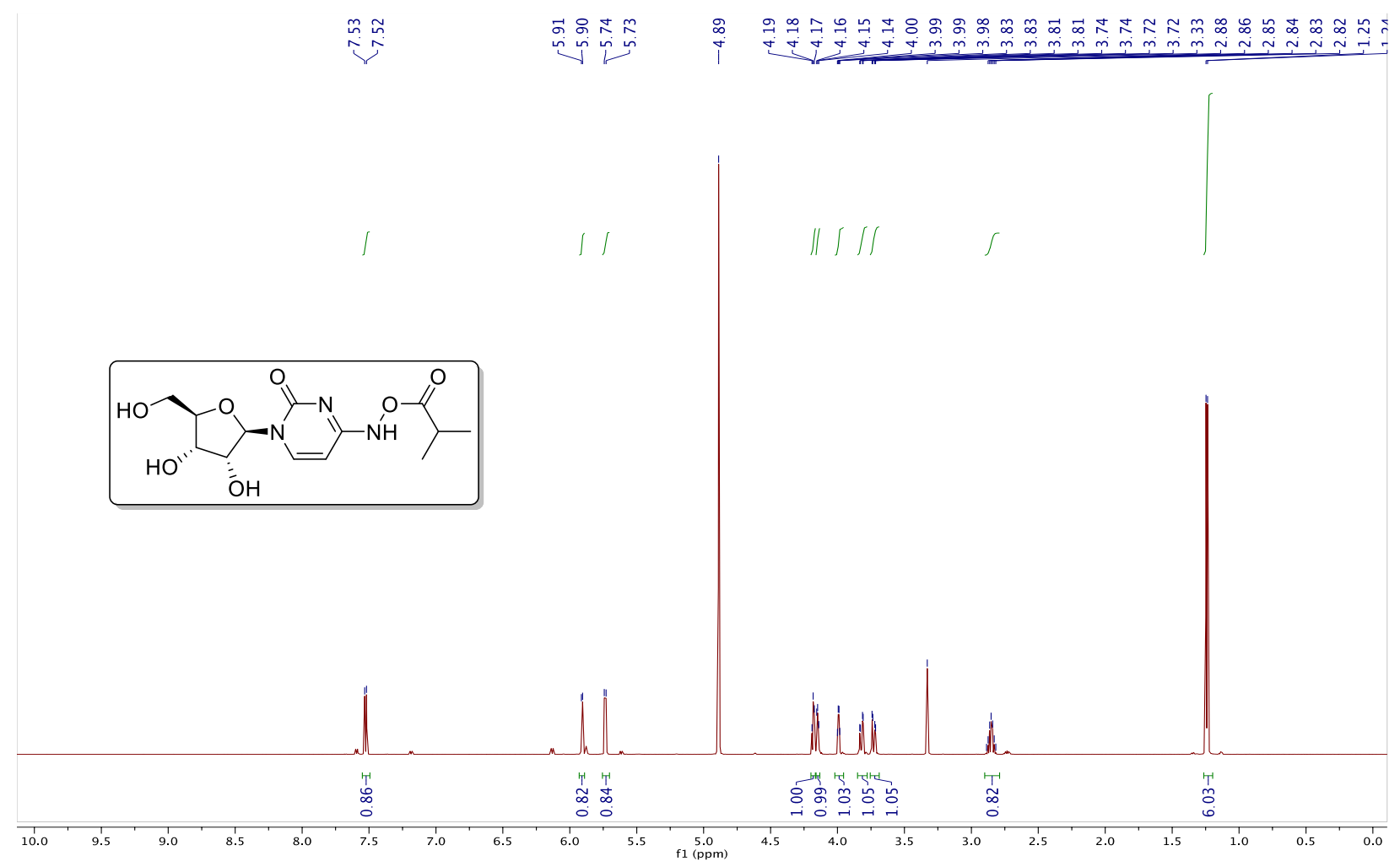

${ }^{13} \mathrm{C}$ NMR Spectra of $\mathrm{N}$-hydroxycytidine oxime ester in $\mathrm{CD}_{3} \mathrm{OD}$ at $151 \mathrm{MHz}$ :

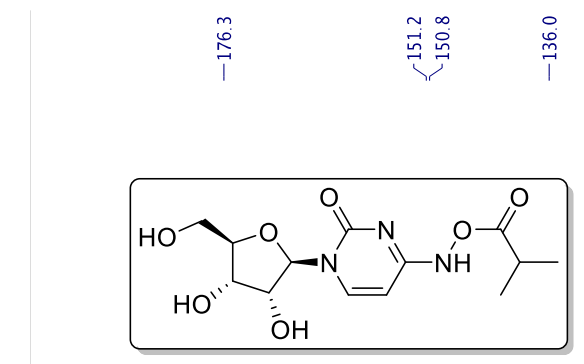

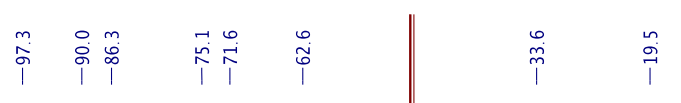

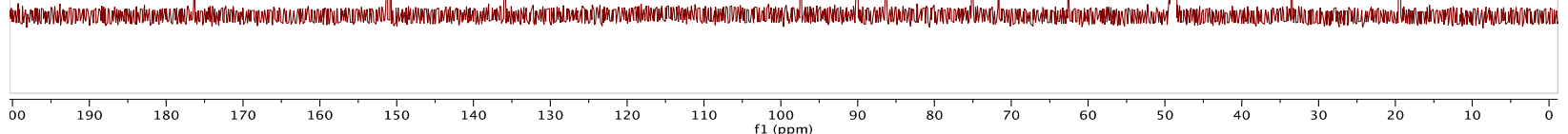


${ }^{1} \mathrm{H}$ NMR Spectra of Molnupiravir oxime ester in $\mathrm{CD}_{3} \mathrm{OD}$ at $600 \mathrm{MHz}$ :

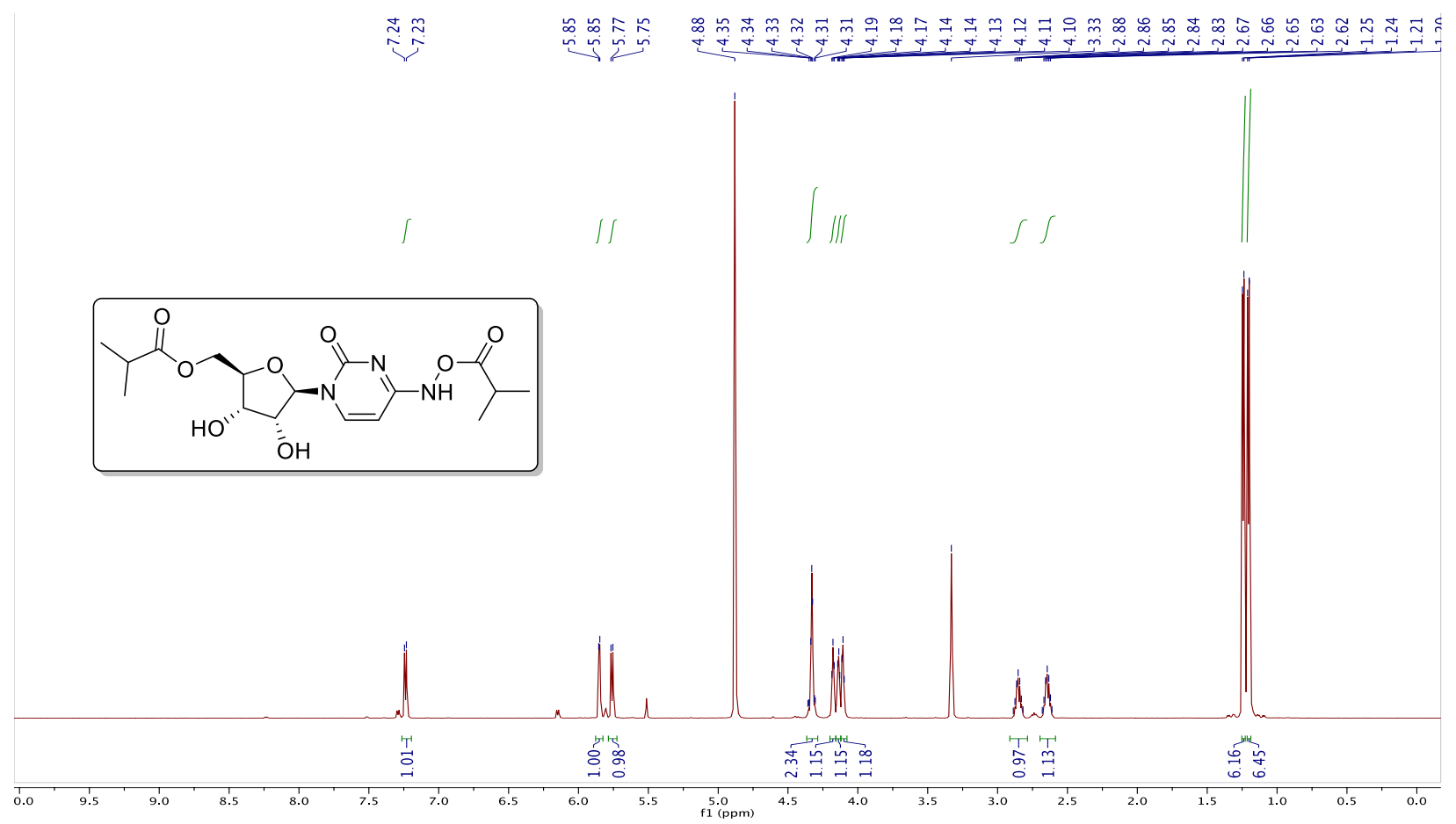

${ }^{13} \mathrm{C}$ NMR Spectra of Molnupiravir oxime ester in $\mathrm{CD}_{3} \mathrm{OD}$ at $151 \mathrm{MHz}$
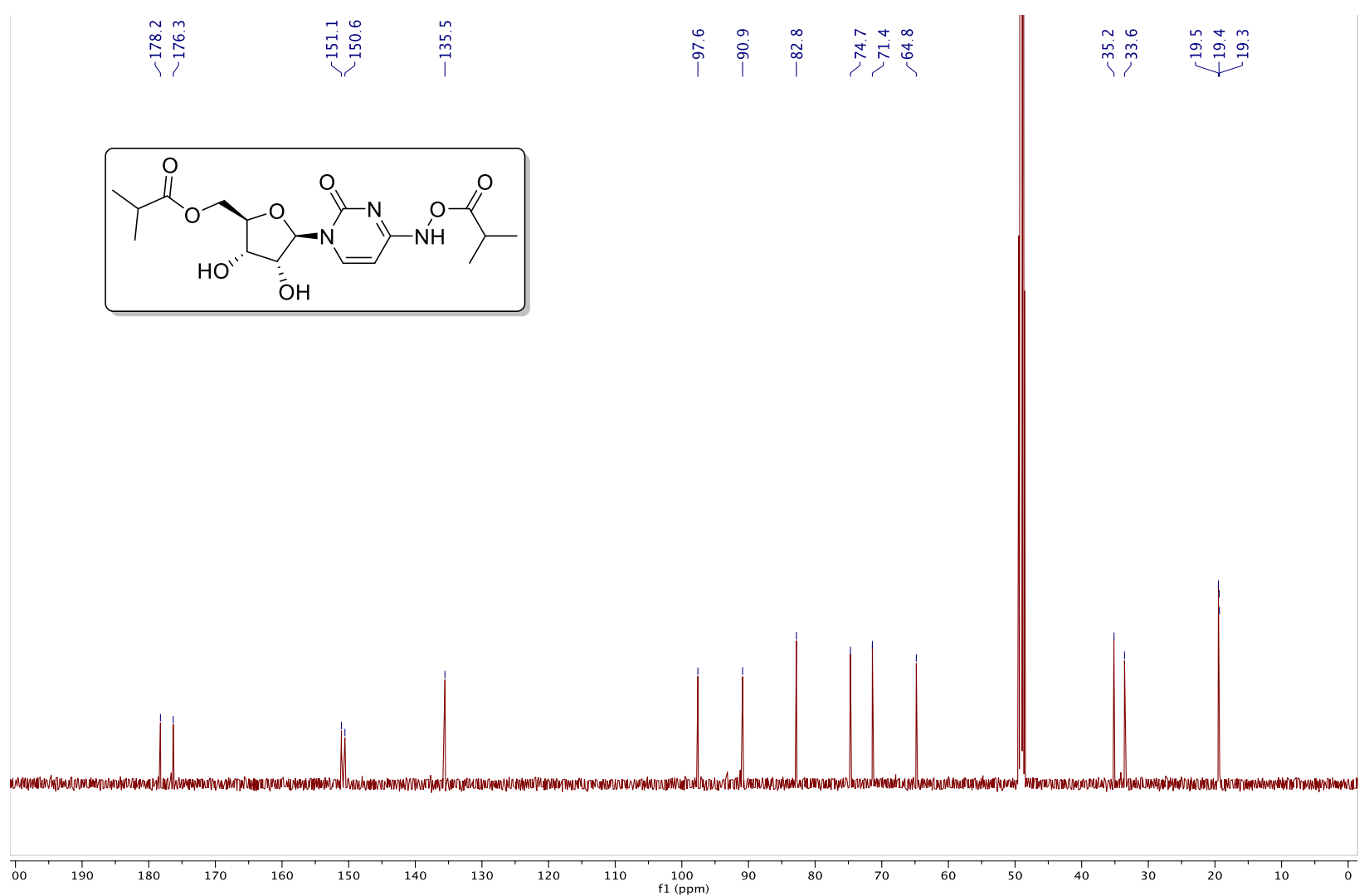
${ }^{1} \mathrm{H}$ NMR Spectra of Molnupiravir (MK-4482; EIDD-2801) in $\mathrm{CD}_{3} \mathrm{OD}$ at $600 \mathrm{MHz}$

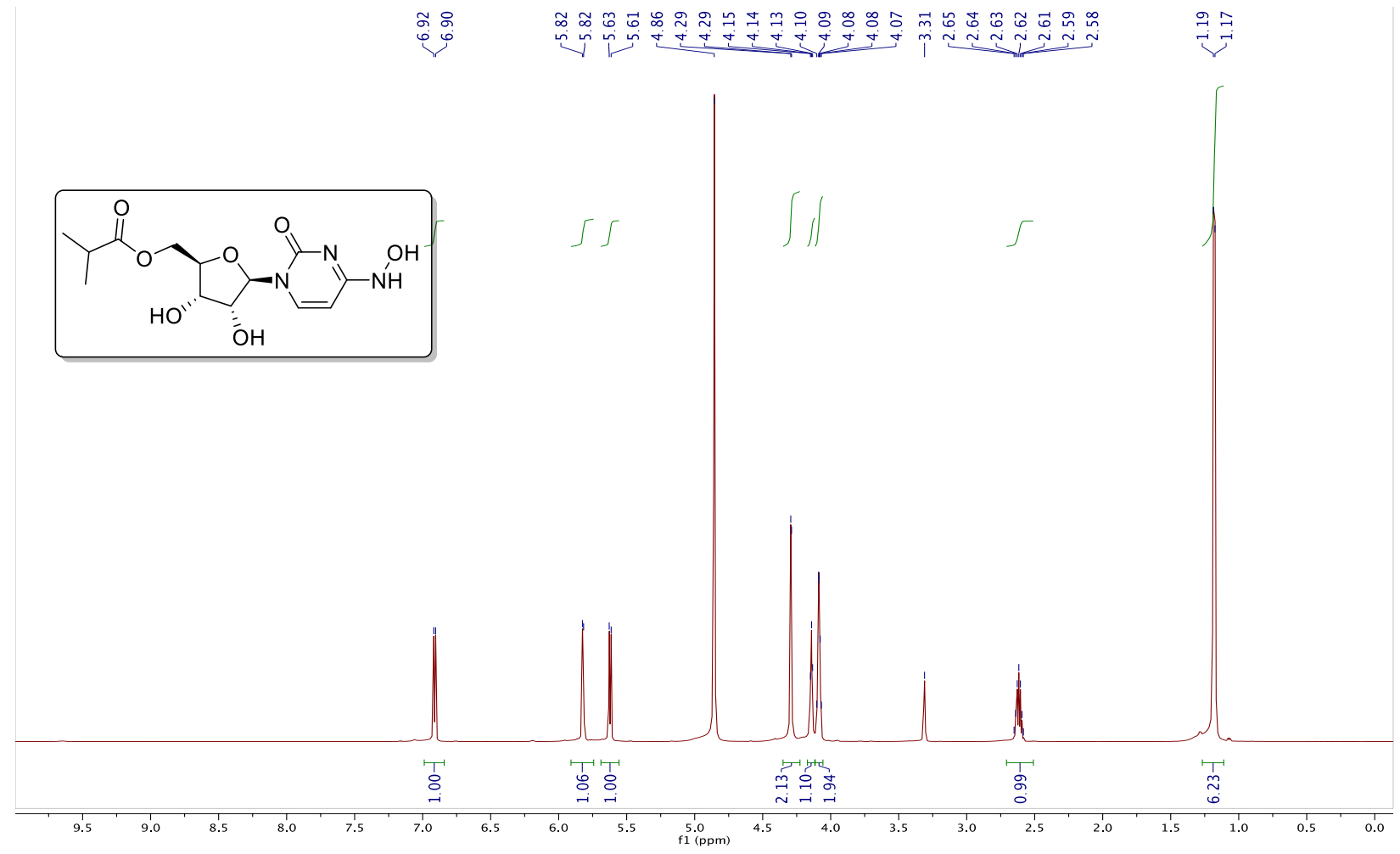

${ }^{13} \mathrm{C}$ NMR Spectra of Molnupiravir (MK-4482; EIDD-2801) in CD $\mathrm{CDD}_{3}$ at $151 \mathrm{MHz}$
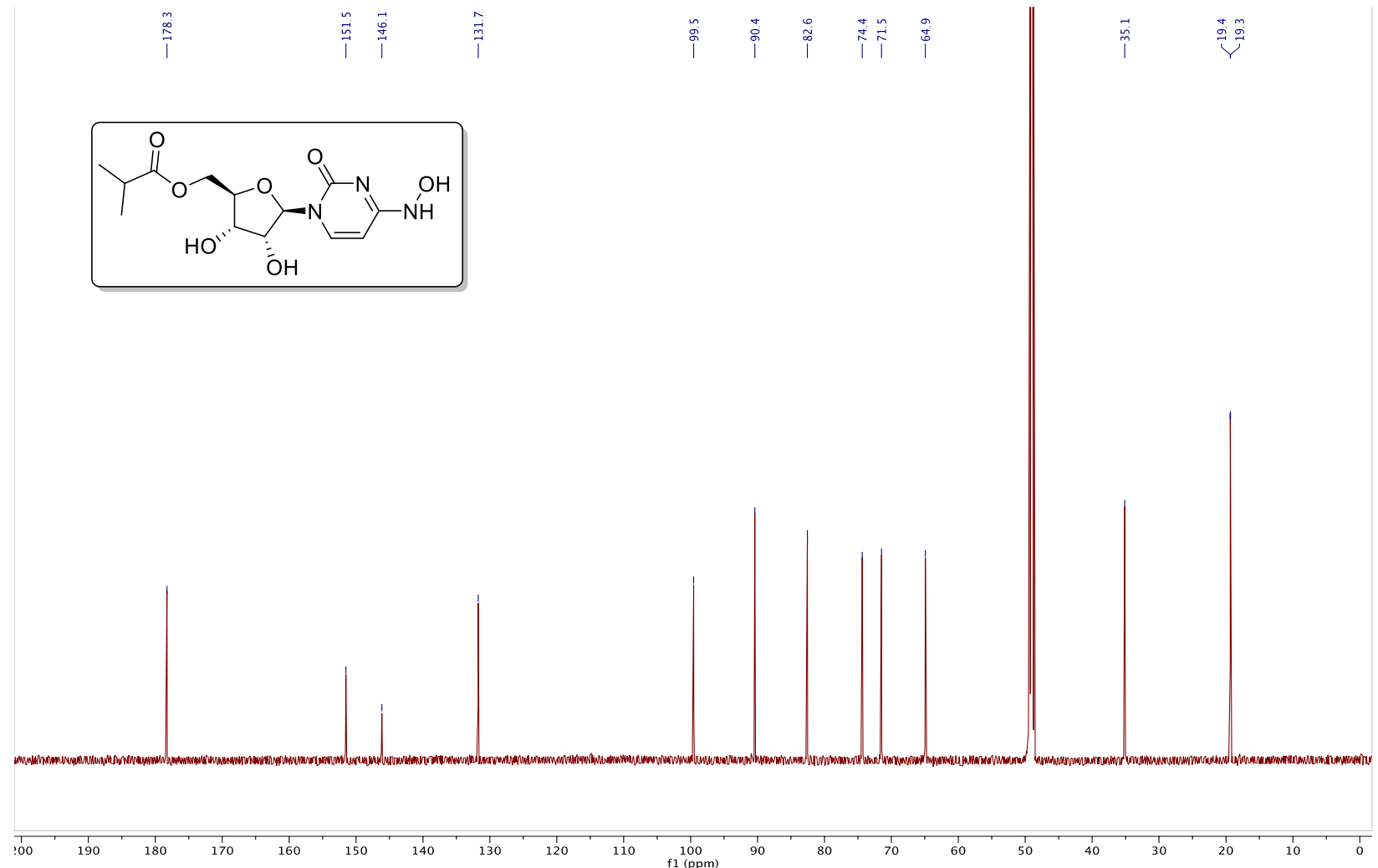


\section{Analytical Method and HPLC Chromatograms:}

Project: EIDD-2801

Purpose: Reaction monitoring of cytidine Method ID: EIDD_Gradient_20200623

starting material and intermediates
Date: June 23, 2020

NOTE: This method is intended for reaction monitoring only

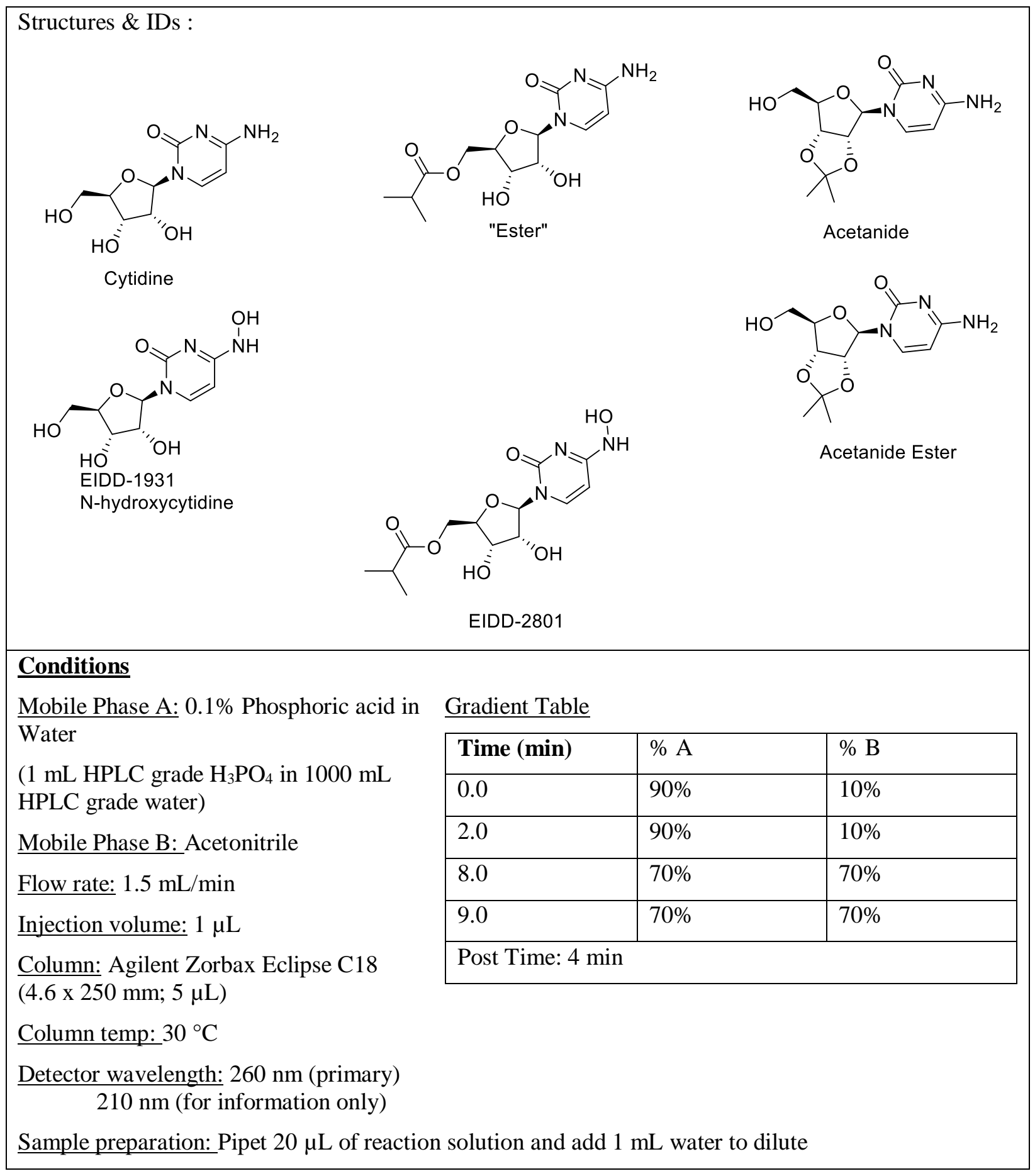




\begin{tabular}{|c|c|}
\hline \multicolumn{2}{|c|}{ Retention Times } \\
\hline \multirow[t]{2}{*}{ Compound } & Time (min) \\
\hline & Gupton LC \\
\hline Cytidine & 1.73 \\
\hline Hydroxylamine & 2.09 \\
\hline \multicolumn{2}{|l|}{ Ester } \\
\hline \multirow[t]{2}{*}{ Acetanide } & 6.77 \\
\hline & Stringham LC \\
\hline EIDD-1931 (NHC) & 1.52 \\
\hline EIDD-2801 Isomer & 5.66 \\
\hline EIDD-2801 & 5.83 \\
\hline Di-substituted EIDD-2801 (1) & 7.58 \\
\hline Di-substituted EIDD-2801 (2) & 7.93 \\
\hline Oxime (Only visible at $210 \mathrm{~nm}$ ) & 7.99 \\
\hline
\end{tabular}

\section{Representative Chromatogram (NVD-148-01)}

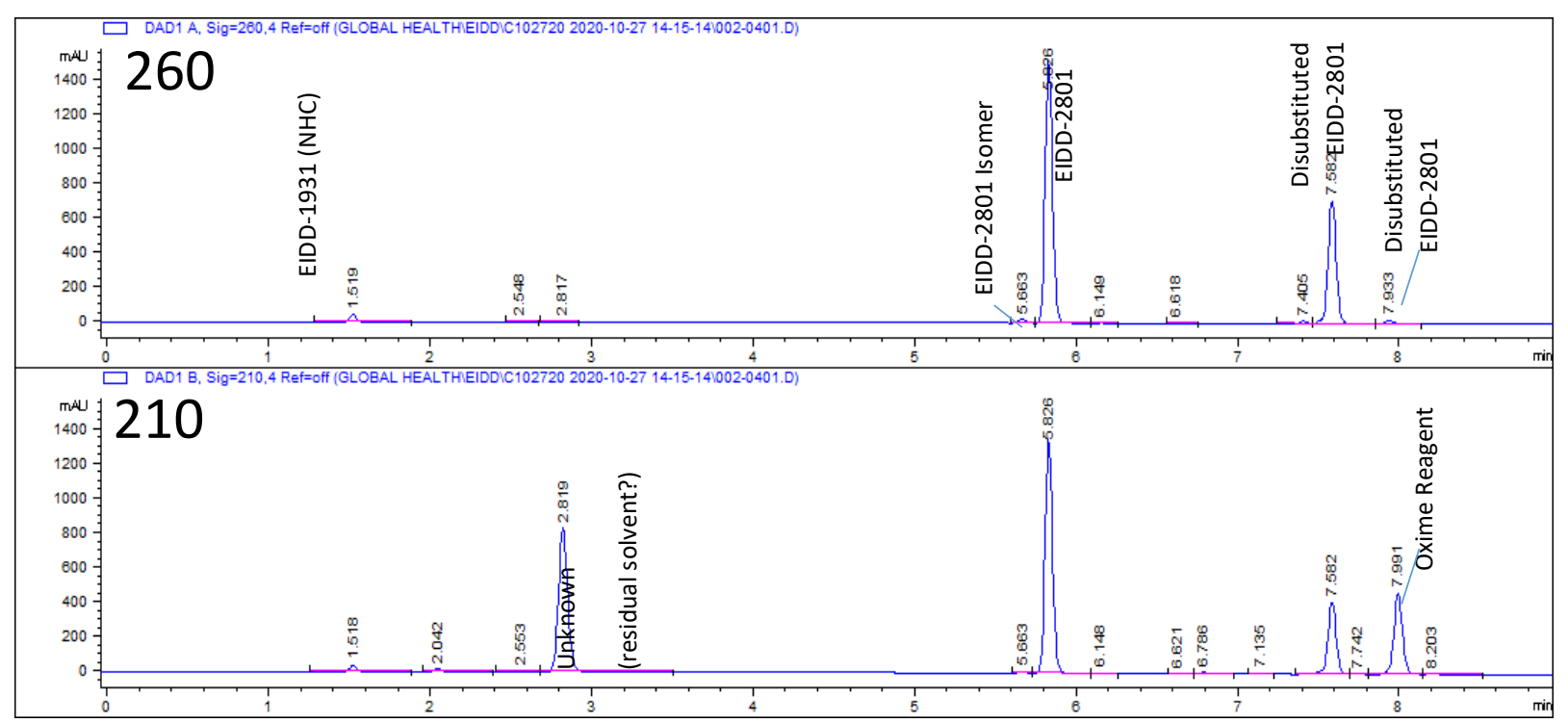


Notes:
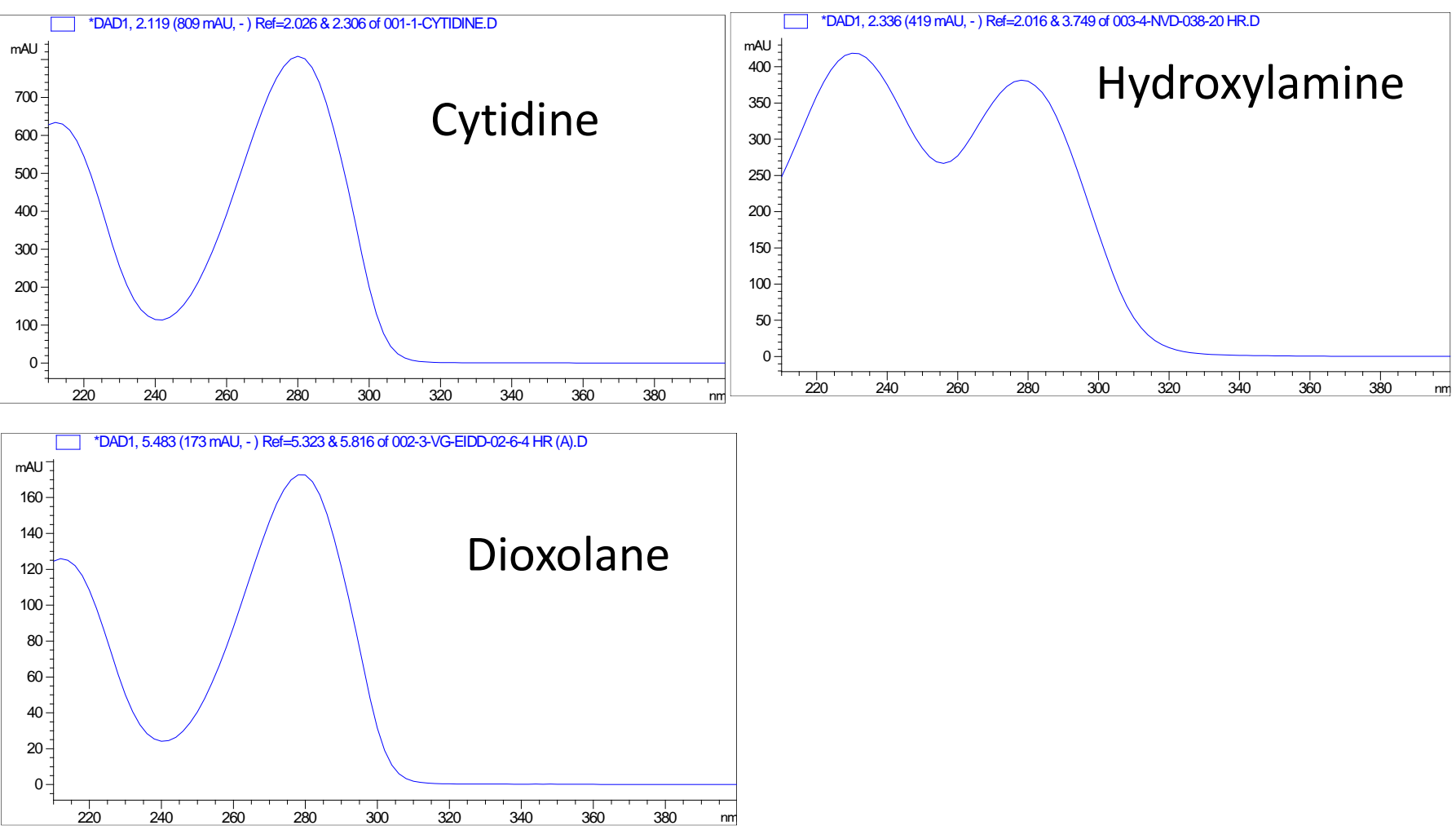